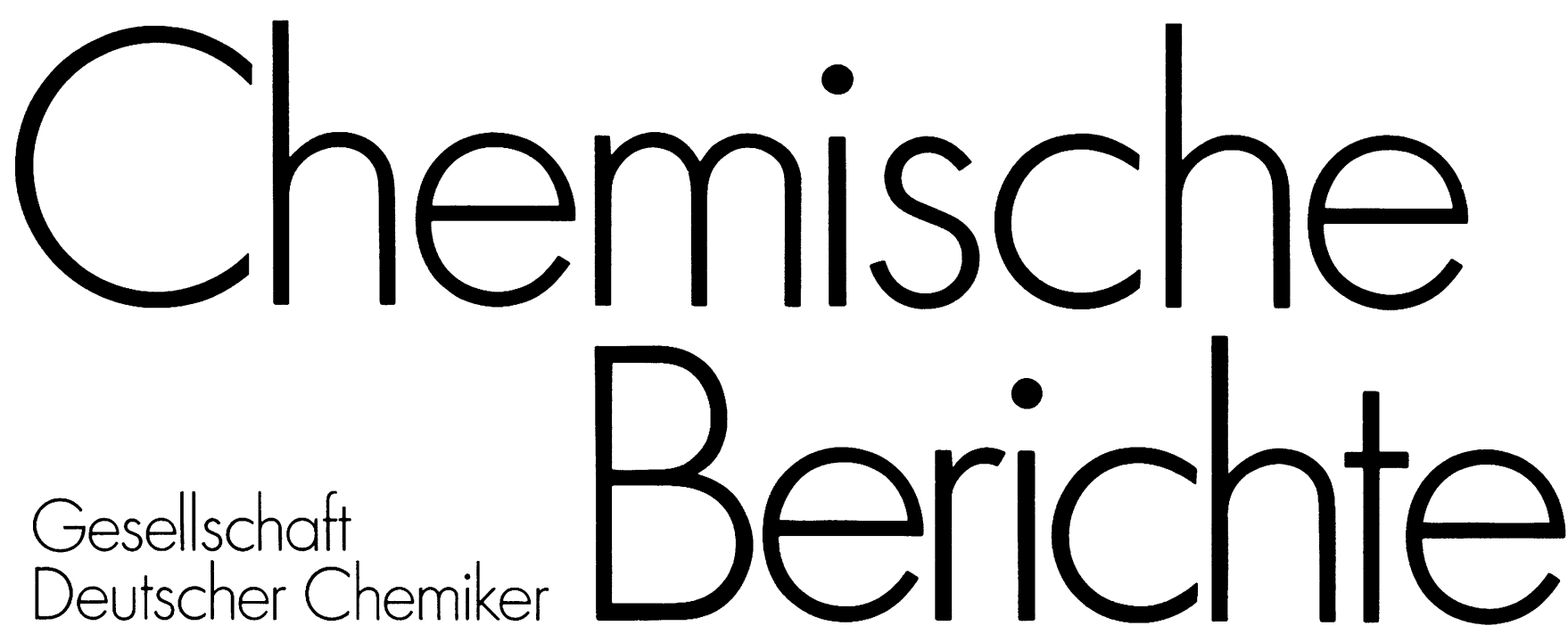

\title{
Founded 1868
}

January $1994 \cdot$ Volume $127 \cdot$ Issue $1 \cdot$ Pages 1- 274

$\begin{array}{lll}\text { Editorial Board: } & \text { Wolfgang Beck } & \text { Martin Jansen } \\ & \text { Rolf Gleiter } & \text { Klaus Müllen } \\ & \text { Klaus Hafner } & \text { Heinrich Nöth } \\ & \text { Henning Hopf } & \text { Werner Schroth }\end{array}$

Managing Editor: Robert Temme

Associate Editors: Udo Eberhardt

Johannes Strehlow

\section{Administration: Hannelore Holm \\ Production: Olga Olivecká}

\begin{abstract}
Helmut Schwarz
Werner Tochtermann

Heinrich Vahrenkamp
\end{abstract}

$\begin{array}{ll}\text { Editorial Office: } & \text { Chemische Berichte } \\ & \text { P.O. Box 101161 } \\ & \text { D-69451 Weinheim } \\ & \text { Federal Republic of Germany } \\ & \text { Telephone (internat.) }+496201606-255 \\ & \text { Telefax (internat.) }+496201606-328\end{array}$

Chemische Berichte

D-69451 Weinheim

Telephone (internat.) $+496201606-255$
Telefax (internat.) $\quad+496201606-328$
Die Chemischen Berichte erscheinen monatlich. Die Bezugsbedingungen für Mitglieder der Gesellschaft Deutscher Chemiker werden auf Anfrage von der Geschäftsstelle, Carl-Bosch-Haus, Varrentrappstraße 40-42, Postfach 900440 , D-60444 Frankfurt, mitgeteilt. Bestellungen richten Sie bitte an Ihre Fachbuchhandlung oder unmittelbar an den Verlag. Abbestellungen nur bis spätestens 3 Monate vor Ablauf des Kalenderjahres. Die Lieferung erfolgt auf Rechnung und Gefahr des Empfängers. Gerichtsstand und Erfüllungsort: Weinheim.

Subscription rates (1994) including postage and handling:

Annual subscription: DM 1590. - (Germany), ÖS 11468. - (Austria), SFr 1468. - (Switzerland), GB£ 647. - (Great Britain), US\$ 1030. - (USA), DM 1617. - (elsewhere); single issue: DM 152. - (Germany; elsewhere on request).

Back volumes of Chemische Berichte are available on microfilm (further information and prices on request).
For the USA and Canada: Chemische Berichte (ISSN 0009-2940) is published monthly by VCH Publishers, Inc., 303 N.W. 12th Avenue, Deerfield Beach FL 33442-1788; Telefax (305) 428-8201; Telephone (305) 428-5566 or (800) 422-8824. Second-class postage paid at Deerfield Beach FL 33441. Annual subscription price: US $\$ 1030.00$, single issue: US $\$ 107.00$ including postage and handling charges. Reduced rate for individual members of the American Chemical Society on request. - Printed in the Federal Republic of Germany.

U.S. POSTMASTER: Send address changes to Chemische Berichte, c/o VCH Publishers, Inc., 303 N.W. 12th Avenue, Deerfield Beach FL 33442-1788.

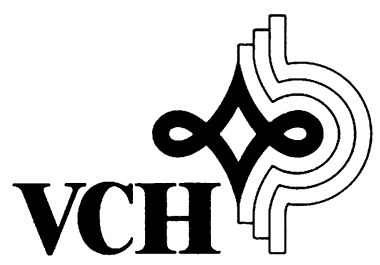


Abele, H., 145

Amrein, W., 97

Anders, C., 231

Bauer, I., 173

Binger, P., 39

Bläser, D., 73

Bock, H., 55

Boese, R., 73, 173, 191

Boldt, P., 219

Born, D., 173

Braunschweig, H., 91

Buchweitz, J., 23

Bussenius, J., 247

Butenschön, H., 137

Carell, T., 223

Cremer, D., 173

Dau-Schmidt, J.-P., 205, 213

de Meijere, A., 237

Döhling, A., 223

Döring, D., 219

Eberbach, W., 247

Englert, U., 87, 93

Enk, M., 127

Feucht, C., 113

Fiegenbaum, P., 127

Frey, R., 101

Gabor, B., 39

Gompper, R., 23

Haas, A., 145

Hanack, M., 113
Hansmersmann, U., 127

Haske, S., 73

Heidel, H., 271

Helmchen, G., 271

Herrmann, W. A., 47

Hintze, F., 267

Hohla, M., 119

Hünig, S., 165

Huttner, G., 271

Jeitschko, W., 15

Jones, P. G., 219

Jutzi, P., 107

Kalinowski, H.-O., 191, 201

Karraß, S., 261

Kaschube, W., 127

Kauffmann, T., 127

Klaunzer, N., 165

Kleine, M., 47

Köhler, J. E. H., 119

König, W. A. 119

Köpper, H., 219

Krieger, C., 231

Krüger, C., 39

Krynitz, U., 55

Kuck, D., 151

Kühn, F. E., 47

Laber, N., 247

Langhauser, F., 39

Lieb, M., 145

Lindermeier, T., 107
Linßen, T., 113

Linti, G., 101

Maier, G., 173, 191, 201

Mayr, H., 205, 213

Meuret, J., 55

Meyer, F., 93

Mink, J., 47

Mix, A., 107

Müller, T., 247

Mynott, R., 39

Näther, C., 55

Neumann, B., 107

Neumann, E., 151

Neumüller, B., 67

Niediek, K., 67

Nöth, H., 81

Nürnberg, O., 27

Paetzold, P., 87, 91, 93

Papenberg, M., 127

Polborn, K., 23, 101

Raabe, N., 261

Richters, M., 119

Robl, C., 23, 97

Romão, C. C., 47

Rückemann, A., 231

Sailer, M.-T., 23

Sander, W., 267

Schäfer, M., 27

Schmid, G., 73

Schneider, L., 87
Schuster, A., 151

Schwarz, H., 261

Sitzmann, H., 3

Spaniol, T. P., 91

Staab, H. A., 223, 231

Stammler, H.-G., 107

Stolpmann, H., 81

Thomann, M., 81

Toliopoulos, E., 127

Tremel, W., 11, 15

Trog, R.-S., 219

Untiedt, S., 237

Vogel, R., 271

Vomhof, T., 15

Walsh, R., 237

Wedemann, P., 39

Weigand, W., 23, 97

Welke, S., 127

Wenner, H., 165

Werner, H., 27

Wolf, J., 27

Wolf, R., 173, 191, 201

Wolmershäuser, G., 3

Wortmann, U., 15

Wünsch, R., 97

Zaika, D., 73

Zhou, P., 3

Zwingenberger, J., 145

\section{Bemerkungen der Redaktion}

1. Die Chemischen Berichte (zu zitieren als Chem. Ber.) setzen seit 1946 die Berichte der Deutschen Chemischen Gesellschaft (zu zitieren als Ber. Dtsch. Chem. Ges.) fort. Die „Berichte“ enthalten Arbeiten aus dem Bereich der Anorganischen und Elementorganischen Chemie (Teil A) sowie der Organischen und Physikalisch-Organischen Chemie (Teil B). Bei der Organischen Chemie liegt der Schwerpunkt auf allgemeinen synthetischen Methoden und mechanistischen Problemen.

2. Die „Berichte“ erscheinen monatlich; ein Register beschließt jeden Jahrgang.

3. Die Verantwortung für ihre Mitteilungen tragen die Verfasser selbst. Der Korrespondenzautor ist durch einen hochgestellten Stern hervorgehoben. Die Zugehörigkeit der Autoren zu den Instituten ist durch hochgestellte Kleinbuchstaben markiert.

4. Es werden grundsätzlich nur Arbeiten aufgenommen, die vorher weder im Inland noch im Ausland veröffentlicht worden sind.

5. Eine Anweisung zur Abfassung von Manuskripten für die „Berichte“ wird auf Wunsch zugestellt (siehe auch Heft 1, S. AI).

6. Manuskripte (in dreifacher Ausfertigung) sind zu senden an Redaktion der Chemischen Berichte, Dr. R. Temme, Postfach 101161, D-69451 Weinheim: Telefon (06201) 606-255.

7. Der Eingang der Abhandlungen wird den Autoren am Tage der Registrierung angezeigi.

8. Es werden nur Manuskripte in deutscher oder englischer Sprache aufgenommen. Allen Beiträgen ist eine knappe Zusammenfassung in Englisch voranzustellen.

9. Der Autor muß das alleinige Urheberrecht besitzen. Mit der Annahme des Manuskriptes durch die Redaktion überträgt er der $\mathrm{VCH}$ Verlagsgesellschaft das ausschließliche Nutzungsrecht, insbesondere das Recht der Vervielfältigung wie Fotokopie, Mikrofilm - oder mit irgendeinem anderen Verfahren - oder das Manuskript in eine von Maschinen. insbesondere von Datenverarbeitungsmaschinen, verwendbare Sprache zu übergeben oder zu übersetzen (auch in fremde Sprachen).

10. Den Autoren werden 25 Sonderdrucke unentgeltlich portofrei zugesandt. Wünscht ein Autor mehr als 25 Abzüge, so ist dies auf dem Manuskript oder spätestens bei Rücksendung der Korrektur auf dieser zu vermerken. Den Autoren werden nur die Selbstkosten für die Zahl der die Freiexemplare überschreitenden Sonderabzüge berechnet.

11. Anfragen nach dem Verbleib nicht eingetroffener Berichte-Hefte oder Sonderdrucke sind $\mathrm{zu}$ richten an: VCH Verlagsgesellschaft $\mathrm{mbH}$, Postfach 101161, D-69451 Weinheim, Telefon (06201) 606-0.

\section{Notice to Authors}

1. Chemische Berichte (abbreviated Chem. Ber; until 1946 Berichte der Deutschen Chemischen Gesellschaft, abbreviated Ber. Dtsch. Chem. Ges.) publishes articles on studies in inorganic and organometallic chemistry (Part A) as well as in organic and physical organic chemistry (Part B). In organic chemistry, emphasis is given to general synthetic methods and mechanistic problems.

2. Chemische Berichte is published monthly; the annual volume concludes with a List of Authors and a List of Contents.

3. Authors are solely responsible for their contributions. - The author to whom correspondence should be addressed should be indicated by an asterisk. Different addresses of coauthors should be given in lower-case letters.

4. The contents of a manuscript submitted to Chemische Berichte should not have been published previously, nor submitted to any other journal. except in the form of brief preliminary communication.

5. For the preparation of manuscripts, a copy of the "Instructions for Authors" is available on request (see also issue 1, p. AI).

6. Manuscripts should be submitted in triplicate to: Redaktion Chemische Berichte, Dr. R. Temme, P.O. Box 101161, D-69451 Weinheim (FRG); Telephone (internat.) + $496201606-255$.

7. Acknowledgement of receipt of the manuscript will be confirmed on the day of registration.

8. Manuscripts may be submitted in German or in English. All contributions must be accompanied by a summary in English.

9. It is assumed that the authors concerned have the necessary authority for publication. Upon acceptance for publication, VCH Verlagsgesellschaft acquires all publishing rights including those of reprinting, translating or reproducing and distributing the manuscript in other forms (e.g. as photocopy, microfilm or in machine-readable form). Moreover, the provisions of the copyright law of the Federal Republic of Germany apply.

10. The author will receive one copy of the galley proofs, together with the edited manuscript and a reprint order form; the author will receive 25 reprints free of charge and may order additional copies at cost price.

11. All inquiries concerning journals or reprints should be addressed to: $\mathrm{VCH}$ Verlagsgesellschaft mbH. P.O. Box 101161, D-69451 Weinheim (FRG). Telephone (internat.) +496201 606-0. 


\section{A Teil A: Anorganische und elementorganische Chemie / Part A: Inorganic and Organometallic Chemistry}

Sitzmann*, H., Zhou, P., Wolmershäuser, G.

- Titan-, Zirconium- und Hafniumkomplexe mit 1,2,4-

Tri-tert-butylcyclopentadienyl-Liganden

Titanium, Zirconium and Hafnium Complexes with 1,2,4-Tri-tert-butylcyclopentadienyl Ligands

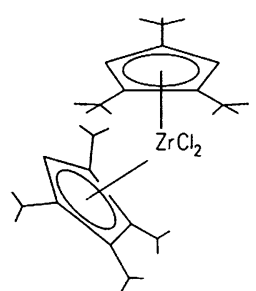

11 Tremel, $\mathbf{W}$.

$\mathrm{Nb}_{4} \mathrm{Te}_{17} \mathrm{I}_{4}$, ein neues pseudo-eindimensionales Festkörper-Polytellurid

- $\mathrm{Nb}_{4} \mathrm{Te}_{17} \mathrm{I}_{4}$, a New Pseudo One-Dimensional SolidState Polytelluride

Tremel*, W., Wortmann, U., Vomhof, T., Jeitschko, W.

- Synthese, Struktur und elektronische Eigenschaften von $\mathrm{Cu}_{0.69} \mathrm{NbTe}_{2}$

Synthesis, Structure and Electronic Properties of $\mathrm{Cu}_{0.69} \mathrm{NbTe}_{2}$
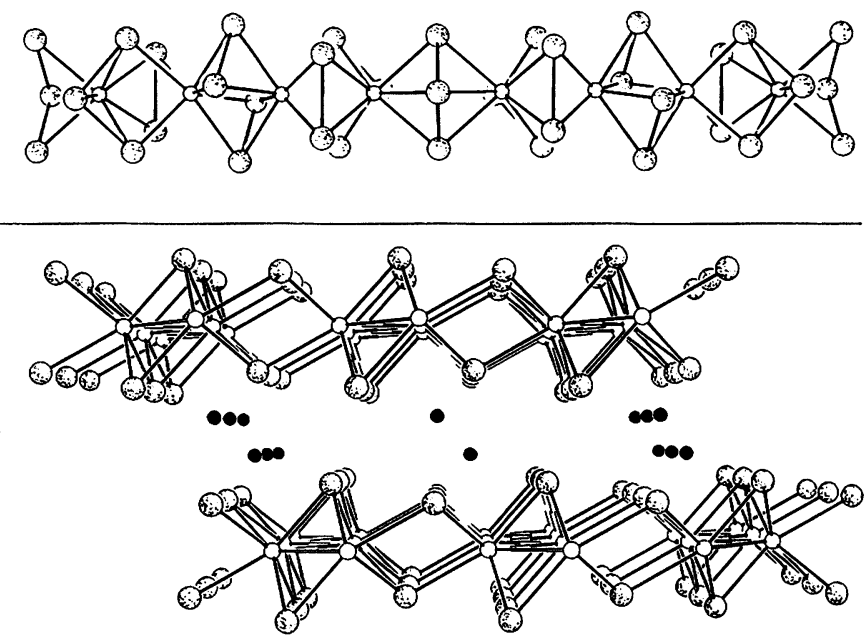

Buchweitz, J., Gompper*, R., Polborn, K., Robl, C., Sailer, M.-T., Weigand*, W.

Funktionalisierte 1,1-Ethendithiolate als Liganden, III. - Palladium(II)- und Platin(II)-Komplexe mit Ferrocenyl-substituierten 1,1-Ethendithiolat-Liganden. Kristallstrukturanalysen von cis $-\left(\mathrm{Ph}_{3} \mathrm{P}\right)_{2} \mathrm{M}\left[\mathrm{S}_{2} \mathrm{C}=\mathrm{CH}-\right.$ $\left.\mathrm{C}(\mathrm{O})-\left(\eta^{5}-\mathrm{C}_{5} \mathrm{H}_{4}\right) \mathrm{Fe}\left(\eta^{5}-\mathrm{C}_{5} \mathrm{H}_{5}\right)\right](\mathrm{M}=\mathrm{Pd}, \mathrm{Pt})$

- Functionalized 1,1-Ethenedithiolates as Ligands, III. - Palladium(II) and Platinum(II) Complexes with Ferrocenyl-Substituted 1,1-Ethenedithiolate Ligands. Crystal Structure Analyses of cis- $\left(\mathrm{Ph}_{3} \mathrm{P}\right)_{2} \mathrm{M}$ $\left[\mathrm{S}_{2} \mathrm{C}=\mathrm{CH}-\mathrm{C}(\mathrm{O})-\left(\eta^{5}-\mathrm{C}_{5} \mathrm{H}_{4}\right) \mathrm{Fe}\left(\eta^{5}-\mathrm{C}_{5} \mathrm{H}_{5}\right)\right](\mathrm{M}=\mathrm{Pd}$, $\mathrm{Pt}$ )

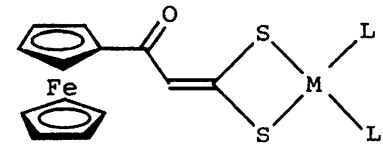

5a: $\mathrm{M}=\mathrm{Pd}, \mathrm{L}=\mathrm{PPh}_{3}$

5b: $M=P t, L=\mathrm{PPh}_{3}$

5c: $M=P t, L=1 / 2$ dppe

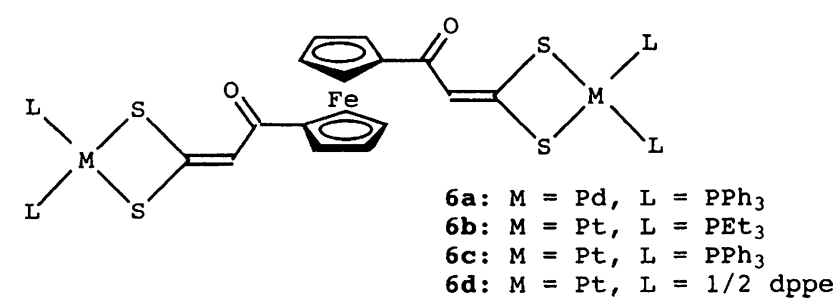

Werner*, H., Schäfer, M., Nürnberg, O., Wolf, J.

- $\eta^{3}$-Allyl- und $\eta^{3}$-Benzyl-Rhodiumkomplexe: Synthese, Strukturdynamik und Reaktionen mit Carbonsäuren $\eta^{3}$-Allyl- and $\eta^{3}$-Benzyl Rhodium Complexes: Synthesis, Structure Dynamic, and Reactions with Carboxylic Acids

$$
\begin{array}{ll}
L=P^{2} P_{3} ; R=H, M e, P h \\
L=P M e_{3} ; R=M e
\end{array}
$$


Binger*, P., Langhauser, F., Wedemann, P.,

Gabor, B., Mynott, R., Krüger, C.

- Allenkomplexe des Titanocens und Zirkonocens: Darstellung und Reaktivität

Allene Complexes of Titanocene and Zirconocene: Synthesis and Reactivity<smiles></smiles><smiles>[R]C([R])=C1CCC(=C([R])[R])[R17]1c1ccccc1</smiles>

\begin{tabular}{r|ll} 
4,5 & $\mathrm{R}$ & $\mathrm{R}^{\prime}$ \\
\hline $\mathbf{a}$ & $\mathrm{H}$ & $\mathrm{H}$ \\
b & $\mathrm{H}$ & $\mathrm{Ph}$ \\
c & $\mathrm{Me}$ & $\mathrm{Me}$ \\
d & $\mathrm{Ph}$ & $\mathrm{Ph}$
\end{tabular}

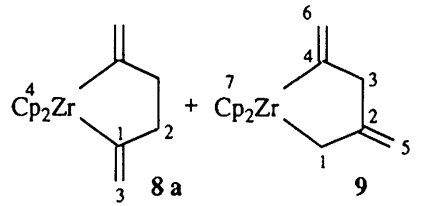<smiles>[R]C([R])C1CCC(C([R])[R])C1[R16]</smiles>

Herrmann*, W. A., Kühn, F. E., Romão, C. C., Kleine, M., Mink, J.

- Mehrfachbindungen zwischen Hauptgruppenelementen und Übergangsmetallen, CXXIX. - Chlorotrioxorhenium. Neue Synthesen, Reaktionen und Derivate

Multiple Bonds between Main Group Elements and Transition Metals, CXXIX. - Chlorotrioxorhenium. Novel Syntheses, Reactions, and Derivatives

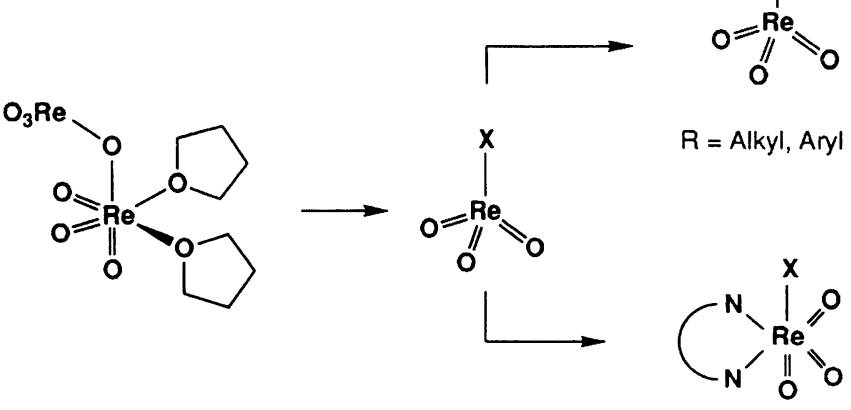

$X=\mathrm{Cl}, \mathrm{Br}, \mathrm{F}, \mathrm{CN}, \mathrm{SCN}, \mathrm{OReO}_{3}$
Bock*, H., Meuret, J., Näther, C., Krynitz, U.

Strukturen sterisch überfüllter und ladungsgestörter Moleküle, 38. - Die verschiedenartigen Konformationen $N$-Trimethylsilyl-substituierter $p$-PhenylendiaminDerivate: Untersuchungen an Einkristallen sowie in der Gasphase

Structures of Sterically Overcrowded and Charge-Perturbed Molecules, 38. - The Different Conformations of $N$-Trimethylsilyl-Substituted $p$-Phenylenediamine Derivatives: Investigation of Single Crystals and in the Gas Phase
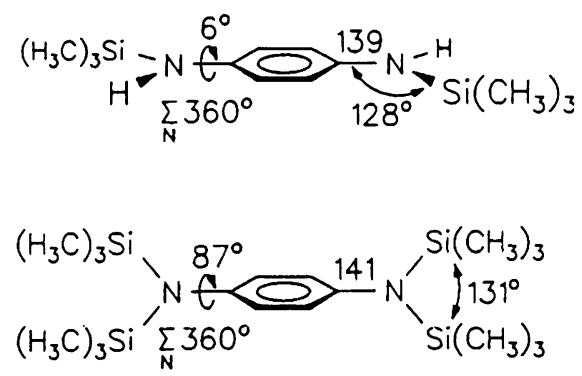

Niediek, K., Neumüller*, B.

Synthese und Charakterisierung von Gallium-Phosphor-Heterocubanen

- Synthesis and Characterization of Gallium-Phosphorus Heterocubanes

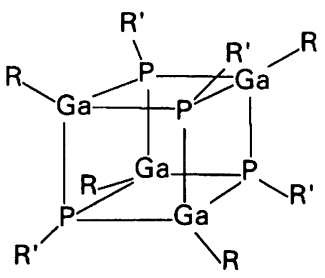

1: $\mathrm{R}=\operatorname{Pr}$

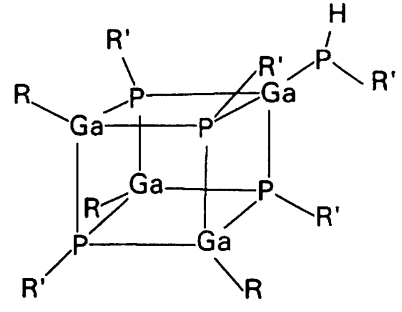

2: $R=$ Mes

$\mathrm{R}^{\prime}=t \mathrm{Bu}$ 
Schmid*, G., Haske, S., Zaika, D., Boese, R., Bläser, D.

1,2-Azaborolyl-Komplexe, XXIX. - Synthese und Eigenschaften von 1,2-Azaborolylboranen

- 1,2-Azaborolyl Complexes, XXIX. - Synthesis and Properties of 1,2-Azaborolylboranes

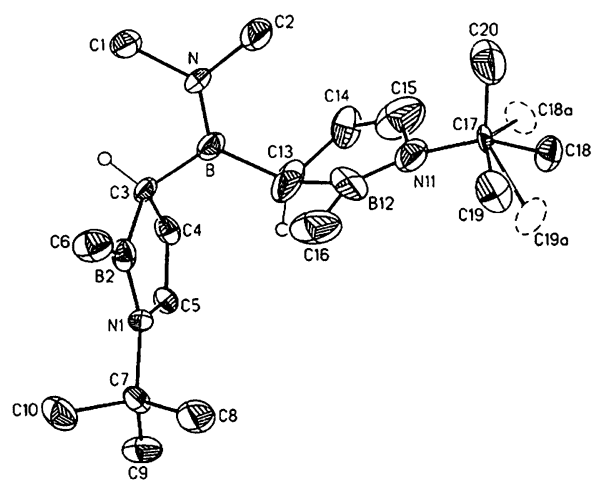

81

Nöth*, H., Stolpmann, H., Thomann, M.

- Beiträge zur Chemie des Bors, 221. - Kinetische und thermodynamische Produktkontrolle bei der Addition von HX-Verbindungen an ein Amino-phosphanylimino-boran $\mathrm{R}_{2} \mathrm{~N}-\mathrm{B} \equiv \mathrm{N}-\mathrm{PR}_{2}^{\prime}$

Contributions to the Chemistry of Boron, 221. - Kinetic and Thermodynamic Product Control in the Addition of HX Compounds to an Amino Phosphanylimino Borane $\mathrm{R}_{2} \mathrm{~N}-\mathrm{B} \equiv \mathrm{N}-\mathrm{PR}_{2}^{\prime}$

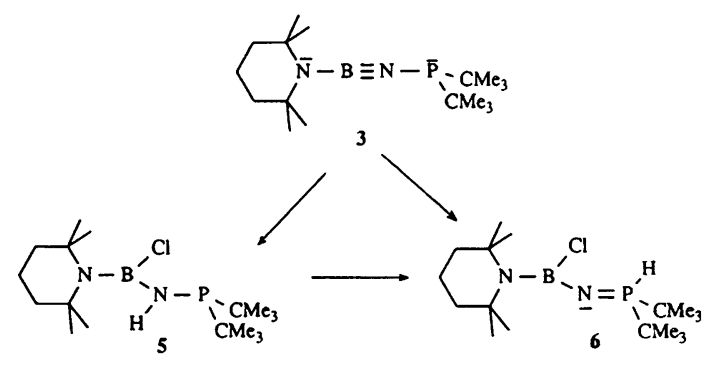

87 Schneider, L., Englert, U., Paetzold*, P.

- Ein neuer Zugang zum ikosaedrischen closo-NB $\mathrm{NB}_{11}-\mathrm{Ge}$ rüst

A Novel Access to the Icosahedral closo $\mathrm{NB}_{11}$ Skeleton

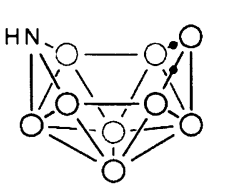

$\frac{+3 \mathrm{~L} \cdot \mathrm{BH}_{3}}{-2 \mathrm{~L}-4 \mathrm{H}_{2}}$ Xylol, $140^{\circ} \mathrm{C}$

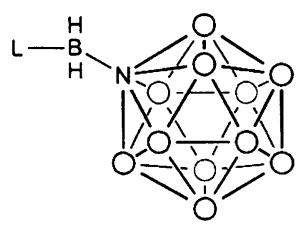

1

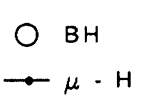

\section{Notizen / Notes}

91

Braunschweig, H., Spaniol, T., Paetzold*, P.

- Zur Bildung eines $\mathrm{Fe}_{2}(\mathrm{CO})_{6}$-Komplexes mit (Boryloxy)allyl-Brücke

On the Formation of a $\mathrm{Fe}_{2}(\mathrm{CO})_{6}$ Complex with a (Boryloxy)allyl Bridge
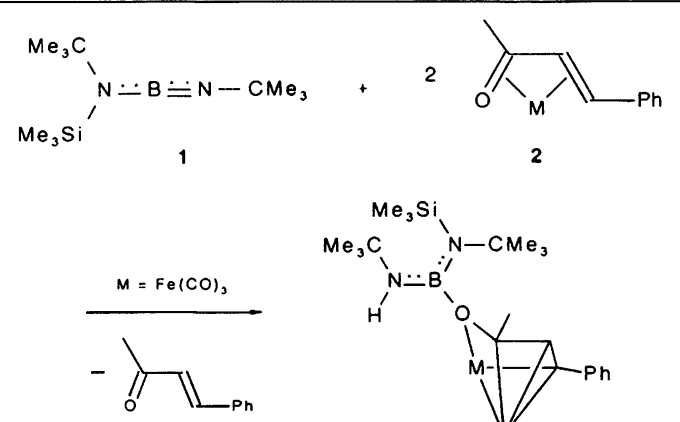

Meyer, F., Paetzold*, P., Englert, U.

- Reaktion von Decaboran mit dem Phosphaalkin $\mathrm{PC} t \mathrm{Bu}$

Reaction of Decaborane with the Phosphaalkyne $\mathrm{PC} t \mathrm{Bu}$

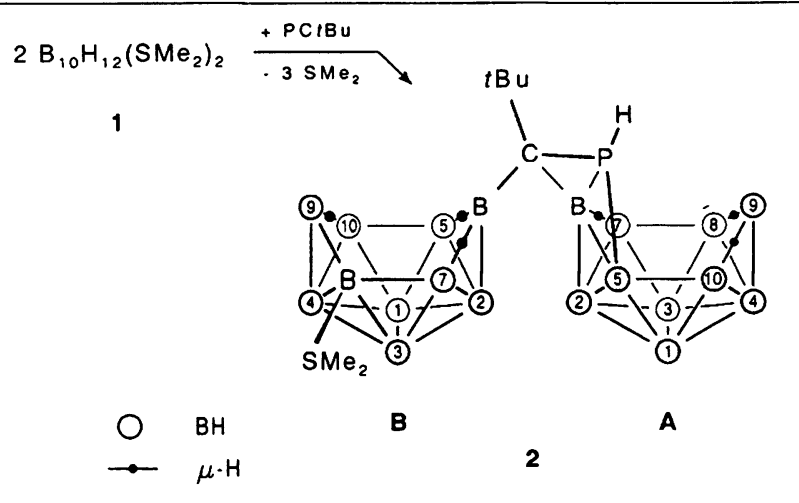


Weigand*, W., Wünsch, R., Robl, C., Amrein, W. Metall-Komplexe von funktionalisierten schwefelhaltigen Liganden, VII. - Synthese von Platin(II)-Alkanund -Arenthiosulfinato-Komplexen - Kristallstrukturanalyse von $N$-[(Benzylsulfinyl)thio]phthalimid

- Metal Complexes of Functionalized Sulfur-Containing Ligands, VII. - Synthesis of Platinum(II) Alkane- and Arenethiosulfinato - Complexes Crystal Structure Analysis of $N$-[(Benzylsulfinyl)thio $]$ phthalimide
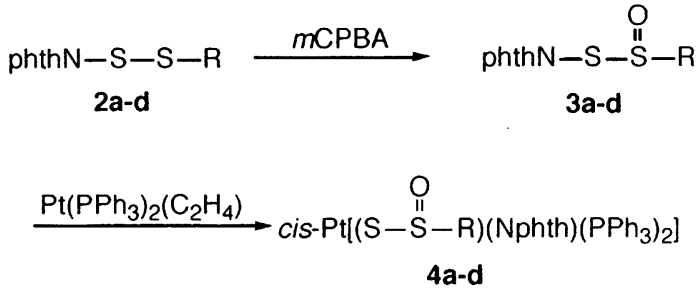

a: $\mathrm{R}=\mathrm{C}_{3} \mathrm{H}_{7}$ b: $\mathrm{R}=\mathrm{C}_{4} \mathrm{H}_{9}$

c: $\mathrm{R}=\mathrm{CH}_{2} \mathrm{C}_{6} \mathrm{H}_{5}$ d: $\mathrm{R}=p-\mathrm{CH}_{3}-\mathrm{C}_{6} \mathrm{H}_{4}$

\section{Frey, R., Linti*, G., Polborn, K.}

- Zur Chemie der Galliumverbindungen, II. - Darstellung und Struktur von Bis(2,2,6,6-tetramethylpiperidino)[tris(trimethylsilyl)silyl]gallium - ein erstes Beispiel für ein monomeres Bis(amino)gallan mit Gallium-Silicium-Bindung

On the Chemistry of Gallium Compounds, II. - Preparation and Structure of Bis(2,2,6,6-tetramethylpiperidino)[tris(trimethylsilyl)silyl]gallium - First Example for a Monomeric Bis(amino)gallane with Gallium Silicon Bond

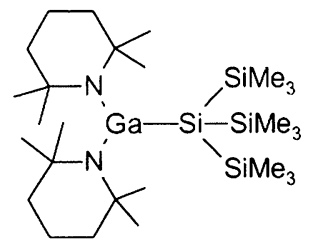

\section{B Teil B: Organische Chemie / Part B: Organic Chemistry}

107

Jutzi*, P., Mix, A., Lindermeier, T., Stammler, H.-G., Neumann, B.

- Bis(pentamethylcyclopentadienyl)methanol: Synthese, Struktur und Derivatisierung

Bis(pentamethylcyclopentadienyl)methanol: Synthesis,
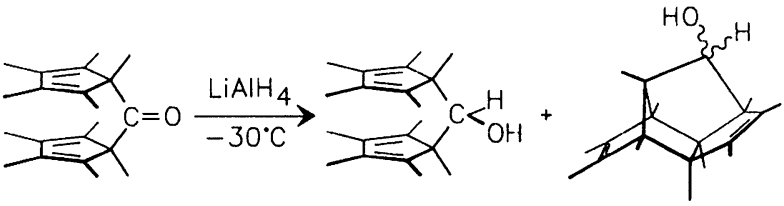

(1)

\section{Feucht, C., Linßen, T., Hanack*, M.}

- Synthese dienophiler und enophiler Phthalocyanine Synthesis of Dienophilic and Enophilic Phthalocyanines
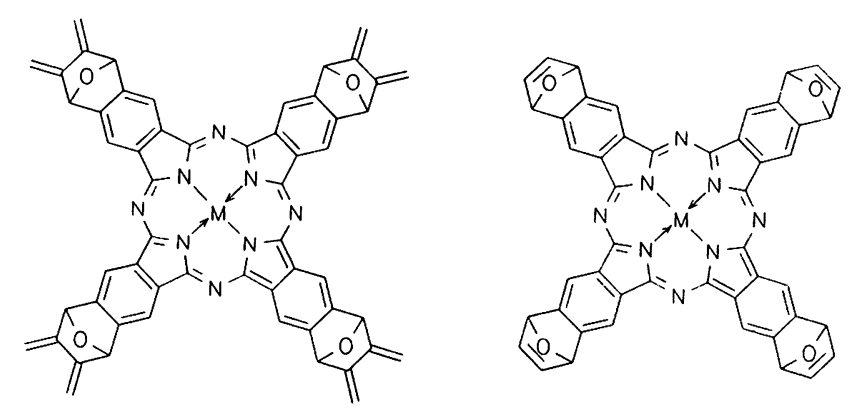

Köhler*, J. E. H., Hohla, M., Richters, M., König, W. A.

Eine moleküldynamische Simulation der Komplex-Bildung zwischen $(R) /(S)$-2-Chlorpropionsäure-methylester und Heptakis(3-O-acetyl-2,6-di- $O$-pentyl)- $\beta$-cyclodextrin

- A Molecular-Dynamics Simulation of the Complex Formation between Methyl $(R) /(S)$-2-Chloropropionate and Heptakis(3-O-acetyl-2,6-di- $O$-pentyl)- $\beta$-cyclodextrin

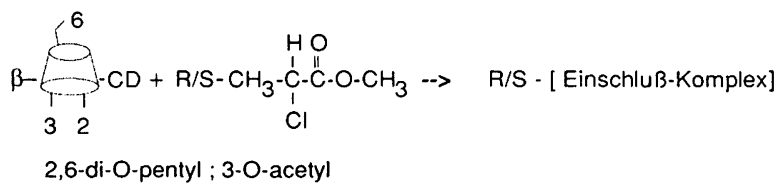


Kauffmann*, T., Enk, M., Fiegenbaum, P., Hansmersmann, U., Kaschube, W., Papenberg, M., Toliopoulos, E., Welke, S.

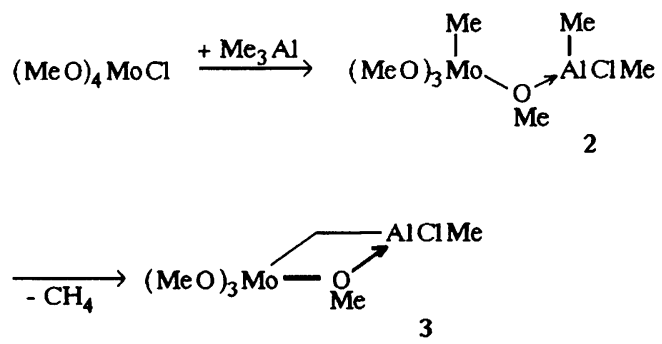

Organomolybdän- und Organowolfram-Reagenzien, VI. - Zur Kenntnis der carbonylmethylenierenden Molybdän-Aluminium- und Wolfram-Aluminium- $\mu$ methylen-Komplexe

Organomolybdenum and Organotungsten Reagents, VI. - On the Carbonyl-Methylenating Molybdenum-Aluminium and Tungsten-Aluminium $\mu$-Methylene Complexes

137

\section{Butenschön, $\mathbf{H}$.}

Synthese von 5-Methoxy- und 5-(Dialkylamino)bicyclo[3.2.0]hept-2-en-6-on-Derivaten durch cine-Substitution mit Methoxid-Anionen und Dialkylaminen

- Synthesis of 5-Methoxy- and 5-(Dialkylamino)bicyclo[3.2.0]hept-2-en-6-one Derivatives by cine Substitution with Methoxide Anions and Dialkylamines
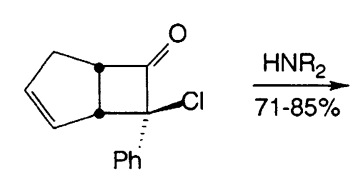<smiles>N[C@]12CC=C[C@H]1[C@H](c1ccccc1)C2=O</smiles>

5

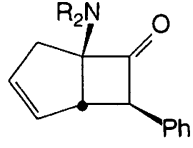

17: $R=E t$
Abele, H., Haas*, A., Lieb, M., Zwingenberger, J.

- Darstellung geeigneter Vorstufen zur Synthese von 16,16,16,17,17,17-Hexafluorretinalen

Preparation of Suitable Precursors for the Synthesis of 16,16,16,17,17,17-Hexafluororetinals<smiles>CC(=O)/C=C/C1C(C)CC=CC1(C(F)(F)F)C(F)(F)F</smiles><smiles>C=CC(C)(O)/C=C/C1C(C)CC=CC1(C(F)(F)F)C(F)(F)F</smiles>

Kuck*, D., Neumann, E., Schuster, A.

Benzo-anellierte Centropolyquinane, 14. - Synthese von Tribenzotriquinacen durch stereokontrollierte Cyclisierung von Phenyl-substituierten $C_{s}$-Diindanen (4ba,9,9a $\alpha, 10$-Tetrahydroindeno[1,2-a]indenen)

- Benzoannellated Centropolyquinanes, 14. - Synthesis of Tribenzotriquinacene by Stereocontrolled Cyclization of Phenyl-Substituted $C_{s}$-Diindans (4ba,9,9a $\alpha, 10$ Tetrahydroindeno[1,2-cl]indenes)

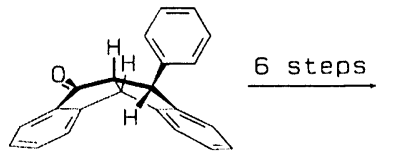

1

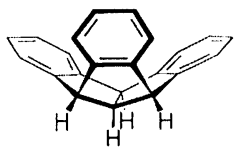

2
Hünig*, S., Klaunzer, N., Wenner $H$.

- Stereoselektive Protonierung von Carbanionen, 2. Diastereoselektive Protonierung von Schöllkopf-Bislactimether-Anionen

Stereoselective Protonation of Carbanions, 2. - Diastereoselective Protonation of Schöllkopf's Bislactim Ether Anions

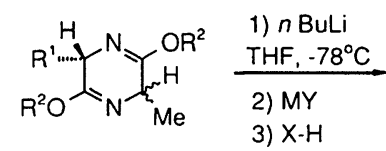

cis / trans $5-7$

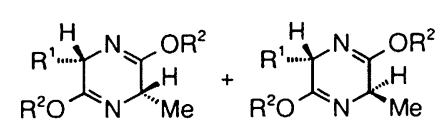

\begin{tabular}{r|r} 
& \multicolumn{2}{|c}{ cis : trans } \\
\hline 5 & $8: 92-89: 11$ \\
$\mathbf{6}$ & $15: 85-74: 26$ \\
7 & $25: 75-59: 41$
\end{tabular}

Maier*, G., Born, D., Bauer, I., Wolf, R., Boese, R., Cremer, D.

- Kleine Ringe, 78. - Tri-tert-butyl(trimethylsilyl)cyclobutadien und Tri-tert-butyl(trimethylsilyl)tetrahedran Small Rings, 78. - Tri-tert-butyl(trimethylsilyl)cyclobutadiene and Tri-tert-butyl(trimethylsilyl)tetrahedrane

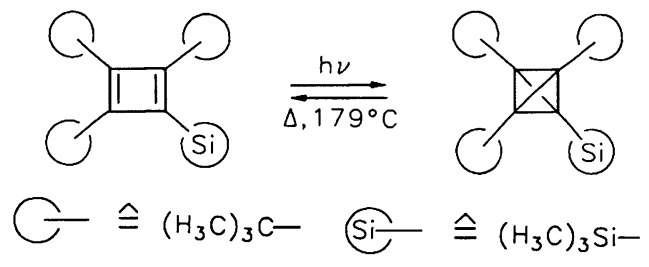

191 Maier*, G., Wolf, R., Kalinowski, H.-O., Boese, $\mathbf{R}$.

- Kleine Ringe, 79. - Synthese und Eigenschaften neuer Silyl-substituierter Cyclobutadiene und Tetrahedrane Small Rings, 79. - Synthesis and Properties of Novel Silyl-Substituted Cyclobutadienes and Tetrahedranes

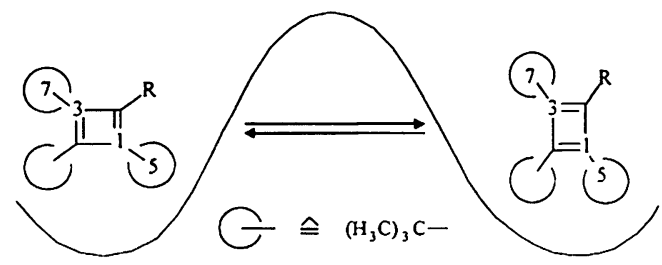


- Kleine Ringe, 80. - Tri-tert-butyl(trimethylgermyl)cyclobutadien und Tri-tert-butyl(trimethylgermyl)tetrahedran

Small Rings, 80. - Tri-tert-butyl(trimethylgermyl)cyclobutadiene and Tri-tert-butyl(trimethylgermyl)tetrahedrane

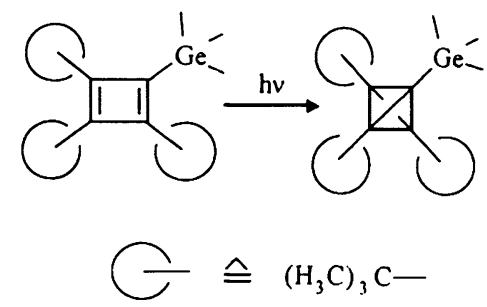

Dau-Schmidt, J.-P., Mayr*, H.

Relative Reaktivitäten von Alkylchloriden unter Friedel-Crafts-Reaktionsbedingungen

- Relative Reactivities of Alkyl Chlorides under FriedelCrafts Conditions

\section{Mayr*, H., Dau-Schmidt, J.-P.}

Relative Reaktivitäten von Acetalen und Ethern unter Friedel-Crafts-Reaktionsbedingungen

- Relative Reactivities of Acetals and Ethers under Friedel-Crafts Conditions
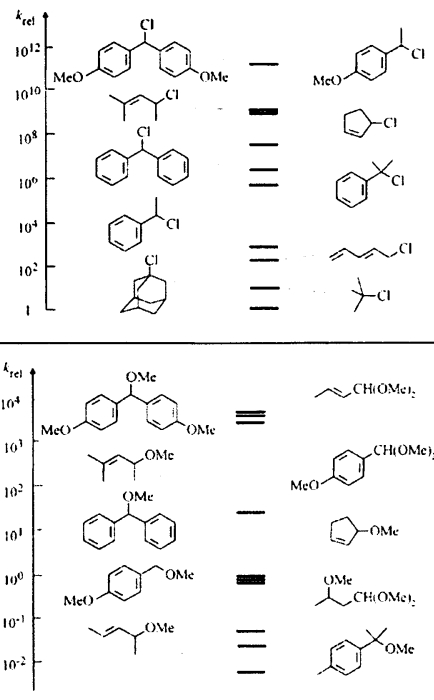

219 Boldt* , P., Döring, D., Jones, P. G., Köpper, H., Trog, R.-S.

- (1 $\alpha, 6 \alpha, 7 \alpha, 8 \alpha, 12 \alpha, 17 \alpha, 18 \alpha, 19 \alpha)$-Heptacyclo[17.3.1.1 $1^{8.12}$. $\left.0^{5.23} \cdot 0^{6.18} \cdot 0^{7.17} \cdot 0^{16.24}\right]$ tetracosa-5(23), 16(24)-dien, ein hyperstabiles Alken

$(1 \alpha, 6 \alpha, 7 \alpha, 8 \alpha, 12 \alpha, 17 \alpha, 18 \alpha, 19 \alpha)$-Heptacyclo[17.3.1.1 $1^{8,12}$. $0^{5.23} \cdot 0^{6.18} \cdot 0^{7.17} \cdot 0^{16.24}$ ]tetracosa-5(23).16(24)-diene, a Hyperstable Alkene

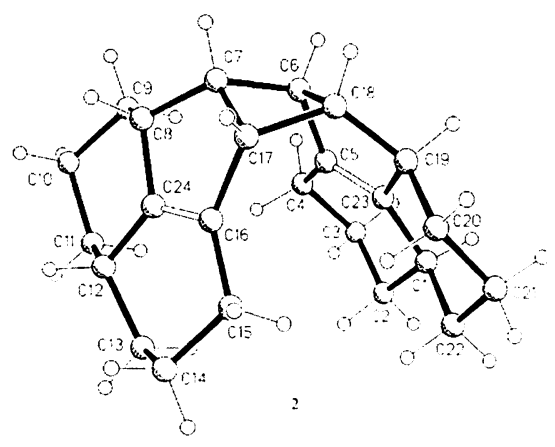

\section{Staab*, H. A., Carell, T., Döhling, A.}

Photoinduzierter Elektronen-Transfer in PorphyrinChinon-Cyclophanen, 9. - Synthese und Eigenschaften neuer Chinon-verbrückter Diphenyl- und Tetraphenylporphyrine

- Photoinduced Electron Transfer in Porphyrin-Quinone Cyclophanes, 9. - Syntheses and Properties of New Quinone-Bridged Diphenyl- and Tetraphenylporphyrins

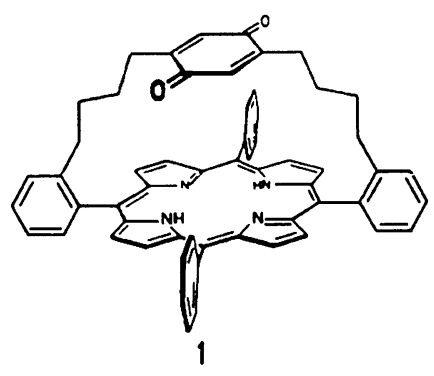

231 Staab*, H. A., Krieger, C., Anders, C., Rückemann, A.

Photoinduzierter Elektronen-Transfer in PorphyrinChinon-Cyclophanen, 10. - Zink-Komplexe von Porphyrin-Chinon-Cyclophanen: Synthesen, Strukturen und Elektronen-Transfer-bezogene Eigenschaften

- Photoinduced Electron Transfer in Porphyrin-Quinone Cyclophanes, 10. - Zinc Complexes of Porphyrin-Quinone Cyclophanes: Syntheses, Structures and ElectronTransfer-Related Properties

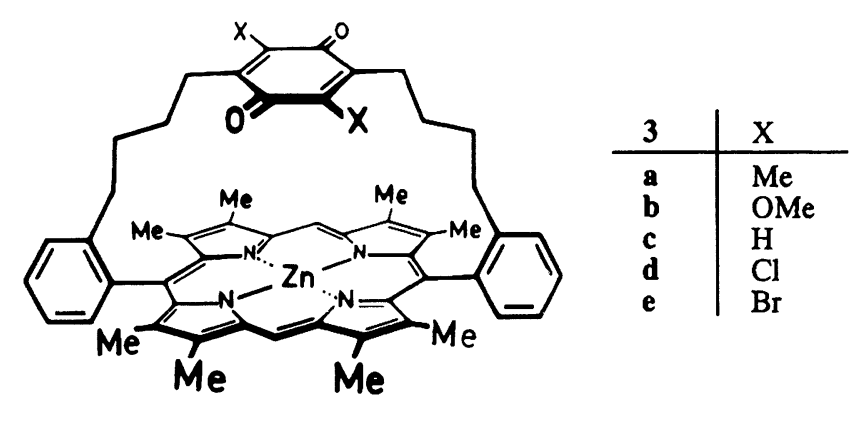


Walsh, R., Untiedt, S., de Meijere*, A.

Gasphasen-Kinetik der Pyrolyse einiger 3,3-Dimethyl1-(trimethylsilyl)cyclopropene - Unerwartete Produkt-Verteilung bei der Cyclopropen-Umlagerung

- Gas-Phase Kinetics of the Pyrolysis of Some 3,3-Dimethyl-1-(trimethylsilyl)cyclopropenes - Unexpected Product Distribution in the Cyclopropene Rearrangement

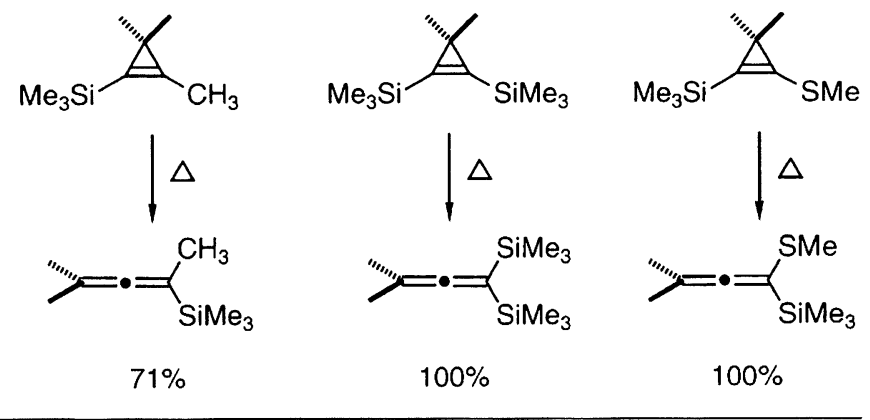

247 Bussenius, J., Laber, N., Müller, T., Eberbach*, W.

- Ein neuer Weg zu isoanellierten Heteroaromaten. 2. Die Dipol-Route zu Furo-/Thieno-Pyrrolen und $\alpha$-Pyridonen, sowie deren Benzo-Derivaten

A Novel Route to Isoannulated Heteroaromatic Com-

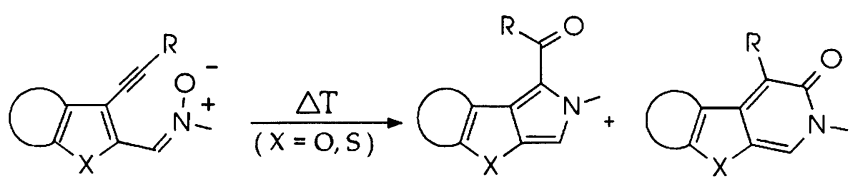
pounds, 2. - The Dipole Route to Furo/Thieno Pyrroles and $\alpha$-Pyridones. and Their Benzo Derivatives

261 Raabe, N., Karraß, S., Schwarz ${ }^{*}$, H.

$\mathrm{Fe}(\mathrm{I})$-vermittelte regio- und stereoselektive $\mathrm{C}-\mathrm{C} /$ $\mathrm{C}-\mathrm{H}$-Bindungs-Aktivierung von internen MethylenGruppen in $\alpha, \omega$-Diphenylalkanen

- $\mathrm{Fe}(\mathrm{I})$-Mediated Regio- and Stereoselective $\mathrm{C}-\mathrm{C} / \mathrm{C}-\mathrm{H}$ Bond Activation of Internal Methylene Groups of $\alpha, \omega$-Diphenylalkanes

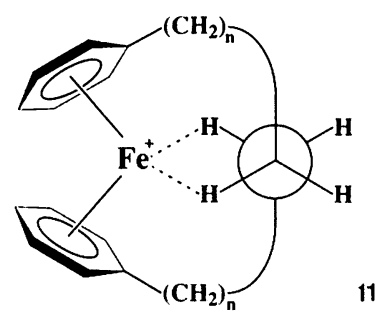

\section{Kurzmitteilungen / Short Communications}

Sander*, W., Hintze, F.

Ein neuer synthetischer Zugang zu Pyridinium- $N$ phenoxid-Betain-Farbstoffen

- A New Synthetic Approach to Pyridinium N-Phenoxide Betaine Dyes

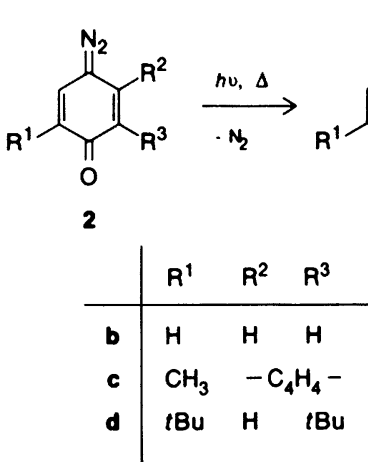

11

Heidel, H., Huttner*, G., Vogel, R.,

Helmchen, G.

- Ein neuartiger chiraler Synthesebaustein mit Neopentangerüst: Chemo-enzymatische Darstellung von $(R)$ $\mathrm{CH}_{3} \mathrm{C}\left(\mathrm{CH}_{2} \mathrm{OSO}_{2} \mathrm{CF}_{3}\right)\left(\mathrm{CH}_{2} \mathrm{Cl}\right)\left(\mathrm{CH}_{2} \mathrm{Br}\right)$

A Novel Chiral Building Block with Neopentane Framework for Synthesis: Chemo-Enzymatic Preparation of $(R)-\mathrm{CH}_{3} \mathrm{C}\left(\mathrm{CH}_{2} \mathrm{OSO}_{2} \mathrm{CF}_{3}\right)\left(\mathrm{CH}_{2} \mathrm{Cl}\right)\left(\mathrm{CH}_{2} \mathrm{Br}\right)$

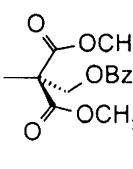

1

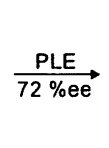

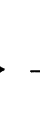<smiles>[R]C(C)=C([R])C(=O)CCC</smiles> 


\title{
Relative Reactivities of Alkyl Chlorides under Friedel-Crafts Conditions
}

\author{
Jan-Peter Dau-Schmidta and Herbert Mayr*b \\ Institut für Chemie, Medizinische Universität zu Lübeck ${ }^{\text {a }}$, \\ Ratzeburger Allee 160, 23538 Lübeck 1, F.R.G. \\ Institut für Organische Chemie, Technische Hochschule Darmstadt ${ }^{\mathrm{b}}$, \\ Petersenstraße 22, 64287 Darmstadt, F.R.G.
}

Received August 2, 1993

Key Words: Alkylation / Allylation / Carbenium ions / Friedel-Crafts reactions / Linear free energy relationships

Competition experiments have been performed to determine the relative reactivities of 23 alkyl chlorides toward allyltrimethylsilane in the presence of catalytic amounts of $\mathrm{ZnCl}_{2}$. The $k_{\text {rel }}$ scale spans over 11 orders of magnitude from 1 -adamantyl chloride (least reactive) to bis( $p$-methoxyphenyl)methyl chloride (most reactive compound). A fair correlation between the alkylating ability and the $S_{N} 1$ reactivity in solvolysis reactions is found, thus providing a quantitative basis for our long-standing working hypothesis that Lewis acid-catalyzed additions of alkyl halides to $\mathrm{CC}$ multiple bonds only yield $1: 1$ products if the reactants ionize faster than the products. Trityl chlorides do not follow this correlation and are $10^{5}$ times less reactive than predicted from their $\mathrm{S}_{\mathrm{N}} 1$ reactivities.
Lewis acid-promoted alkylations of alkenes (eq. 1) yield products 3 which have electrophilic properties like the reactants $\mathbf{1}$, and it depends on the relative electrophilicity of $\mathbf{1}$ and 3 whether the products 3 can be isolated or whether they will react further to give higher adducts or polymers. A high ratio [3]/[1] can only develop in the reaction mixture if product 3 is less reactive than reactant 1 under the reaction conditions.

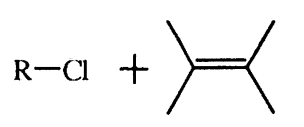

1

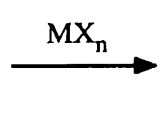

2

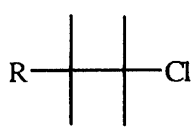

3
Relative reactivities of diarylchloromethanes have been determined by competition experiments, and it has been shown that in the presence of catalytic amounts of Lewis acids the reactivity of $\mathrm{Ar}_{2} \mathrm{CHCl}$ grows with increasing stabilization of the carbenium ion $\mathrm{Ar}_{2} \mathrm{CH}^{+}$(the situation is opposite under conditions of complete ionization! $)^{[1]}$. This result had been anticipated by the postulate that Lewis acidcatalyzed additions of alkyl halides to CC multiple bonds can only lead to $1: 1$ products (eq. 1) if the reactants 1 ionize faster than the products $3^{[2]}$.

We have now investigated the quantitative relationship between relative electrophilicities of alkyl chlorides and their ionization rates as expressed by their $\mathrm{S}_{\mathrm{N}} 1$ reactivities. In contrast to the related study in ref. ${ }^{[1]}$ which was restricted to benzhydryl chlorides, we now report on electrophilicities of alkyl chlorides of large structural variety. Since alkylations of allyltrimethylsilane (4) selectively yield the $S_{E} 2^{\prime}$ products 5 which unlike 3 cannot undergo sequential electrophilic reactions, compound $\mathbf{4}$ has been selected as the reference nucleophile for determining relative electrophilicities of alkyl chlorides by competition experiments (Scheme 1).
Scheme 1

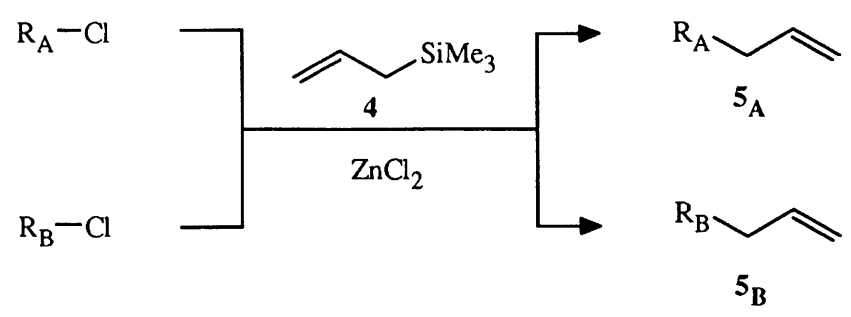

\section{Reaction Products}

Compounds $\mathbf{1 a - y}$ (Table 1) react with allyltrimethylsilane (4) to give compounds $\mathbf{5}$, i.e., the chlorine atom in $\mathbf{1} \mathbf{a}-\mathbf{y}$ becomes substituted by an allyl group. In general, the reactions proceed almost quantitatively, but in few cases the isolated yields of products are relatively low. This is mostly due to losses during workup, since repeated microdistillations are necessary to separate compounds with low boiling points (molecular formula $\leqslant \mathrm{C}_{9}$ ) from hexamethyldisiloxane (b.p. $101^{\circ} \mathrm{C}$ ), which is formed as a byproduct during workup. In order to avoid this problem, allyltrimethylsilane (4) has been replaced by allyltripropylsilane for the synthesis of compounds $5 \mathbf{p}, \mathbf{s}$, and $\mathbf{v}$ (Table 1 ).

Compound $1 \mathbf{p}$ is employed as a mixture containing $19 \%$ of an isomer (4-chloro-4-methyl-2-pentene) that ionizes with formation of the same allyl cation. When this mixture is combined with allyltripropylsilane in the presence of $\mathrm{ZnCl}_{2} \cdot \mathrm{OEt}_{2}$, compound $\mathbf{5 p}$ is formed as the major product, and only $5 \%$ of 4,4-dimethyl-1,5-heptadiene, its allylic isomer, is detected by GC-MS. Analogously, $\mathbf{5 u}$ is produced along with $6 \%$ of its regioisomer [6-methyl-4-(trimethylsilyl)-1,4,5-heptatriene]. Due to decomposition during distillation the yield of $\mathbf{5 s}$ is very low. 
When $1 \mathrm{w}, 4$, and $\mathrm{TiCl}_{4}$ were combined at $20^{\circ} \mathrm{C}$ as described in ref. ${ }^{[3]}$, a viscous oil was formed, which solidified at $20^{\circ} \mathrm{C}$ to give a glassy material. Compound $\mathbf{5 w}$ was obtained in $34 \%$ yield, however, when the reactants were combined with $\mathrm{ZnCl}_{2} \cdot \mathrm{OEt}_{2}$ at $-28^{\circ} \mathrm{C}$ for 6 days.

Table 1. Zinc chloride/ether-catalyzed reactions of allyltrimethylsilane (4) with compounds $\mathbf{1 a}-\mathbf{y}$

\begin{tabular}{|c|c|c|c|c|}
\hline & $\mathrm{RCl}$ & $T /{ }^{\circ} \mathrm{C}$ & Time $/ \mathrm{h}$ & isolated yield / $\%$ \\
\hline $\mathbf{a}$ & $\left(\mathrm{p}-\mathrm{MeOC}_{6} \mathrm{H}_{4}\right)_{2} \mathrm{CH}-\mathrm{Cl}$ & -78 & 1 & 74 \\
\hline b & $\left(\mathrm{p}-\mathrm{MeOC}_{6} \mathrm{H}_{4}\right)\left(\mathrm{p}-\mathrm{MeC}_{6} \mathrm{H}_{4}\right) \mathrm{CH}-\mathrm{Cl}$ & -78 & 1 & 95 \\
\hline c & $\left(\mathrm{p}-\mathrm{MeOC}_{6} \mathrm{H}_{4}\right)\left(\mathrm{C}_{6} \mathrm{H}_{5}\right) \mathrm{CH}-\mathrm{Cl}$ & -78 & 1 & 87 \\
\hline d & $\left(\mathrm{p}-\mathrm{MeC}_{6} \mathrm{H}_{4}\right)_{2} \mathrm{CH}-\mathrm{Cl}$ & -78 & 1 & 92 \\
\hline $\mathbf{e}$ & $\left(\mathrm{p}-\mathrm{MeC}_{6} \mathrm{H}_{4}\right)\left(\mathrm{C}_{6} \mathrm{H}_{5}\right) \mathrm{CH}-\mathrm{Cl}$ & -78 & 1 & 91 \\
\hline f & $\left(\mathrm{C}_{6} \mathrm{H}_{5}\right)_{2} \mathrm{CH}-\mathrm{Cl}$ & -78 & 1 & 87 \\
\hline g & $\left(\mathrm{p}-\mathrm{ClC}_{6} \mathrm{H}_{4}\right)_{2} \mathrm{CH}-\mathrm{Cl}$ & -78 & 3 & 89 \\
\hline h & $\left(\mathrm{C}_{6} \mathrm{H}_{5}\right)_{3} \mathrm{C}-\mathrm{Cl}$ & 25 & 68 & $80^{[a]}$ \\
\hline i & $\left(\mathrm{p}-\mathrm{MeC}_{6} \mathrm{H}_{4}\right) \mathrm{Me}_{2} \mathrm{C}-\mathrm{Cl}$ & -78 & 2 & 92 \\
\hline j & $\left(\mathrm{C}_{6} \mathrm{H}_{5}\right) \mathrm{Me}_{2} \mathrm{C}-\mathrm{Cl}$ & -78 & 60 & 90 \\
\hline k & $\left(\mathrm{p}-\mathrm{MeOC}_{6} \mathrm{H}_{4}\right) \mathrm{MeCH}-\mathrm{Cl}$ & -78 & 2 & 86 \\
\hline 1 & $\left(\mathrm{p}-\mathrm{MeC}_{6} \mathrm{H}_{4}\right) \mathrm{MeCH}-\mathrm{Cl}$ & -78 & 24 & 86 \\
\hline $\mathbf{m}$ & $\left(\mathrm{C}_{6} \mathrm{H}_{5}\right) \mathrm{MeCH}-\mathrm{Cl}$ & -28 & 65 & 79 \\
\hline $\mathbf{n}$ & $\left(\mathrm{p}-\mathrm{MeOC}_{6} \mathrm{H}_{4}\right) \mathrm{CH}_{2}-\mathrm{Cl}$ & -78 & 1.5 & 85 \\
\hline $\mathbf{o}$ & $\left(\mathrm{C}_{6} \mathrm{H}_{5}\right)(\mathrm{MeO}) \mathrm{CH}-\mathrm{Cl}$ & -78 & 15 & 92 \\
\hline p & $\mathrm{Me}_{2} \mathrm{C}=\mathrm{CH}-\mathrm{CHMe}-\mathrm{Cl}$ & -78 & 2 & $\left.58^{[b}, \mathrm{c}\right]$ \\
\hline$q$ & $\left(\overline{\mathrm{CH}_{2}}\right)_{2}-\mathrm{CH}=\mathrm{CH}-\mathrm{C} H-\mathrm{Cl}$ & -78 & 1 & 50 \\
\hline $\mathbf{r}$ & (E)-Me-CH=CH-CHMe-Cl & -78 & 3 & 37 \\
\hline s & (E) $-\mathrm{H}_{2} \mathrm{C}=\mathrm{CH}-\mathrm{CH}=\mathrm{CH}-\mathrm{CH}_{2}-\mathrm{Cl}$ & -40 & 67 & $7[b, d]$ \\
\hline$t$ & $\mathrm{C}_{6} \mathrm{H}_{5}-\mathrm{C} \equiv \mathrm{C}-\mathrm{CMe}_{2}-\mathrm{Cl}$ & -78 & 2 & 91 \\
\hline u & $\mathrm{Me}_{3} \mathrm{Si}-\mathrm{C} \equiv \mathrm{C}-\mathrm{CMe}_{2}-\mathrm{Cl}$ & -78 & 20 & $73[\mathrm{c}]$ \\
\hline $\mathbf{v}$ & $\mathrm{Me}-\mathrm{C} \equiv \mathrm{C}-\mathrm{CMe}_{2}-\mathrm{Cl}$ & -78 & 48 & $50^{\text {bl }}$ \\
\hline$w$ & 1-Adamantyl-Cl & $-28 / 0$ & $144 / 48$ & 34 \\
\hline $\mathbf{x}$ & $\mathrm{Me}_{3} \mathrm{C}-\mathrm{Cl}$ & 0 & 48 & 40 \\
\hline y & $\mathrm{MeO}-\mathrm{CH}_{2}-\mathrm{Cl}$ & .78 & 10 & 24 \\
\hline
\end{tabular}

[a| $\mathrm{SnCl}_{4}$ - - In] Allyltripropylsilane instead of allyltrimethylsilane (4). - ${ }^{|c|}$ Includes 5\% of 4,4-dimethyl-1,5-heptadiene (GC), 1p employed is a mixture with $19 \%$ allylic isomer. - 1 Includes $10 \%$ of impurities (GC). - $|c|$ Includes 6\% of 6-methyl-4-(trimethylsilyl)-1,4,5-heptatriene (GC).

\section{Competition Experiments}

Formal Analysis: Previous work on the mechanism of these reactions suggests the kinetic formalism outlined in Scheme 2.

For the reactions of carbenium ions $\mathrm{R}^{+}$with allyltrimethylsilane (4) second-order kinetics (eq. 2) have been observed $^{[4]}$.

$$
\frac{\mathrm{d}\left[\mathrm{P}_{\mathrm{A}}\right]}{\mathrm{d} t}=-\frac{\mathrm{d}\left[\mathrm{R}_{\mathrm{A}}^{+}\right]}{\mathrm{d} t}=k_{2 \mathrm{~A}}\left[\mathrm{R}_{\mathrm{A}}^{+}\right][4]
$$

If the Lewis acid $\mathrm{MCl}_{n}$ is used in catalytic amounts, a stationary carbenium ion concentration can be assumed, and $\left[R_{A}^{+}\right]$is given by eq. (3).
Scheme 2
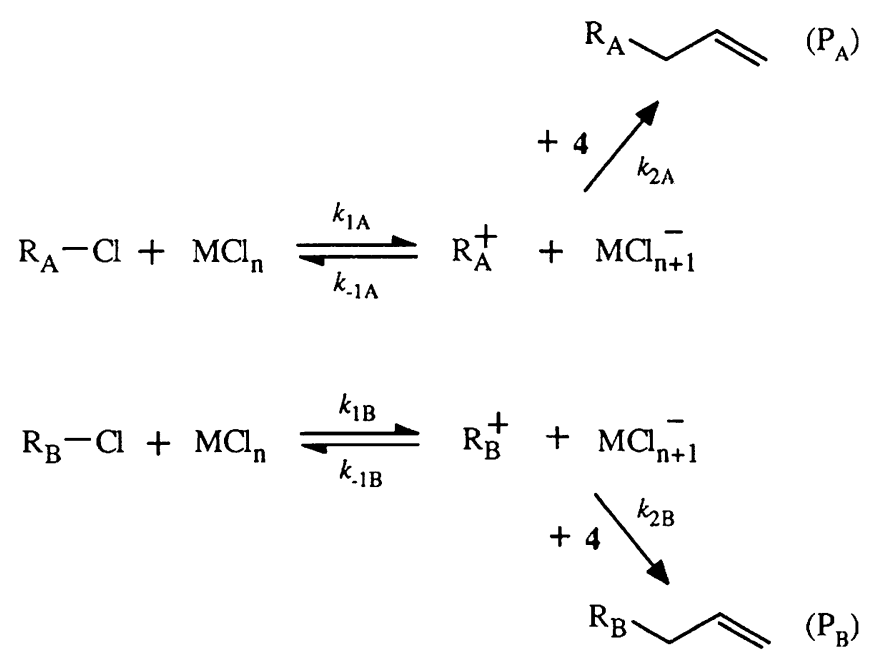

$$
\left[\mathrm{R}_{\mathrm{A}}^{+}\right]=\frac{k_{1 \mathrm{~A}}\left[\mathrm{R}_{\mathrm{A}} \mathrm{Cl}\right]\left[\mathrm{MCl}_{n}\right]}{k_{-1 \mathrm{~A}}\left[\mathrm{MCl}_{n+1}^{-}\right]+k_{2 \mathrm{~A}}[4]}
$$

Eq. (3) implies complete ion pair dissociation, i.e., $v_{-1 \mathrm{~A}}=k_{-1 \mathrm{~A}}\left[\mathrm{R}_{\mathrm{A}}^{+}\right]\left[\mathrm{MCl}_{n+1}^{-}\right]$. If the carbenium ions were partially paired, an additional, first-order ion-pair recombination term had to be considered. As this modification does not affect the general conclusions, it will be neglected in the following.

Substitution of eq. (3) into (2) and combination with analogous equations for $P_{B}$ and $R_{B}^{+}$yields eq. (4).

$$
\frac{\mathrm{d}\left[\mathrm{P}_{\mathrm{A}}\right]}{\mathrm{d}\left[\mathrm{P}_{13}\right]}=\frac{\left.k_{1 \mathrm{~A}} k_{2 \mathrm{~A}}\left[\mathrm{R}_{\Lambda} \mathrm{C}\right]\right]\left(k_{-1 \mathrm{~B}}\left[\mathrm{MCl}_{n+1}^{-}\right]+k_{2 B}[4]\right)}{k_{13} k_{2 B}\left[\mathrm{R}_{\mathrm{B}} \mathrm{Cl}\right]\left(k_{-1 \mathrm{~A}}\left[\mathrm{MCl}_{n+1}^{-}\right]+k_{2 A}[4]\right)}
$$

Three different cases have to be considered:

Case 1: The ionization equilibria described in Scheme 2 are rapidly established, i.e. $k_{-1 \mathrm{~A}}\left[\mathrm{MCl}_{n+1}^{-}\right] \gg k_{2 \mathrm{~A}}[4]$ and $k_{-1 \mathrm{~B}}\left[\mathrm{MCl}_{n+1}^{-}\right] \gg k_{2 \mathrm{~B}}[4]$. Now the second terms of the sums in eq. (4) can be omitted, and the resulting quotients $k_{1 \mathrm{~A}} /$ $k_{-1 \mathrm{~A}}$ and $k_{1 \mathrm{~B}} / k_{-1 \mathrm{~B}}$ can be replaced by the equilibrium constants $K_{1 \mathrm{~A}}$ and $K_{\mathrm{IB}}$, respectively, to yield eq. (5) (CurtinHammett situation).

$$
\frac{\mathrm{d}\left[\mathrm{P}_{\mathrm{A}}\right]}{\mathrm{d}\left[\mathrm{P}_{\mathrm{B}}\right]}=\frac{K_{1 \mathrm{~A}} k_{2 \mathrm{~A}}\left[\mathrm{R}_{\mathrm{A}} \mathrm{Cl}\right]}{K_{1 \mathrm{~B}} k_{2 \mathrm{~B}}\left[\mathrm{R}_{\mathrm{B}} \mathrm{Cl}\right]}
$$

The competition constant $\kappa$ is then given by eq. (6)

$$
\kappa=\frac{K_{1 \mathrm{~A}} k_{2 \mathrm{~A}}}{K_{1 \mathrm{~B}} k_{2 \mathrm{~B}}}
$$

Case 2: If the reaction of $\mathrm{R}^{+}$with the nucleophile 4 is much faster than ion recombination, i.e., $k_{-1 \mathrm{~A}}\left[\mathrm{MCl}_{n+1}^{-}\right] \ll$ $k_{2 \mathrm{~A}}[4]$ and $k_{-1 \mathrm{~B}}\left[\mathrm{MCl}_{n+1}^{-}\right] \ll k_{2 \mathrm{~B}}[4]$, the first terms of the sums in eq. (4) can be omitted to give eq. (7), and the resulting competition constant reflects the ratio of the ionization rate constants (eq. 8). 


$$
\begin{gathered}
\frac{\mathrm{d}\left[\mathrm{P}_{\mathrm{A}}\right]}{\mathrm{d}\left[\mathrm{P}_{\mathrm{B}}\right]}=\frac{k_{1 \mathrm{~A}}\left[\mathrm{R}_{\mathrm{A}} \mathrm{Cl}\right]}{k_{1 \mathrm{~B}}\left[\mathrm{R}_{\mathrm{B}} \mathrm{Cl}\right]} \\
\kappa=\frac{k_{1 \mathrm{~A}}}{k_{1 \mathrm{~B}}}
\end{gathered}
$$

Case 3: If the ion combination $\left(\mathrm{R}^{+}+\left[\mathrm{MCl}_{n+1}^{-}\right]\right)$and the reaction of $\mathrm{R}^{+}$with $\mathbf{4}$ have similar rates, a simplification of eq. (4) is not possible, and eq. (9) shows that $\kappa$, defined as above, is not constant but depends on the concentrations $\left[\mathrm{MCl}_{n+1}^{-}\right]$and [4]. Since, on the other hand, $\left[\mathrm{MCl}_{n+1}^{-}\right]$depends on the concentrations $\left[\mathrm{R}_{\mathrm{A}} \mathrm{Cl}\right]_{0}$ and $\left[\mathrm{R}_{\mathrm{B}} \mathrm{Cl}\right]_{0}$, the value of $\kappa$ may depend on the concentrations of the reactants.

$$
\kappa=\frac{k_{1 \mathrm{~A}} k_{2 \mathrm{~A}}\left(k_{-1 \mathrm{~B}}\left[\mathrm{MCl}_{n+1}^{-}\right]+k_{2 \mathrm{~B}}[4]\right)}{k_{1 \mathrm{~B}} k_{2 \mathrm{~B}}\left(k_{-1 \mathrm{~A}}\left[\mathrm{MCl}_{n+1}^{-}\right]+k_{2 \mathrm{~A}}[4]\right)}
$$

An alternative reaction mechanism, attack of allyltrimethylsilane (4) at $\mathrm{RCl} \cdot \mathrm{ZnCl}_{2}$ complexes was not taken into consideration, since in a case where ionization equilibria and the rate constants $k_{2 \mathrm{~A}}$ and $k_{2 \mathrm{~B}}$ could be independently determined, the observed competition constants were in accord with those calculated from eq. (6) ${ }^{[1]}$. It is conceivable, however, that this reaction mechanism is operative in cases, where the relative reactivities were found to depend on the reactants' ratio (see below).

\section{Results}

Determinations of the relative reactivities of $\mathbf{1 e / 1 \mathbf { f }}$ and of $1 \mathrm{~d} / \mathbf{1}$ e with $\mathrm{BCl}_{3}(15 \%)$ as the Lewis acid gave values between 7 and 12, depending on the reactant ratios ${ }^{[5]}$. Addition of $\mathrm{BnEt}_{3} \mathrm{~N}^{+} \mathrm{BCl}_{4}^{-}$increased the $\mathbf{1 e} / \mathbf{1} \mathbf{f}$ ratio to $16-19$. Obviously, case 3 is realized under these conditions: $\mathrm{BCl}_{4}^{-}$ is a kinetically stable anion, and chloride transfer from $\mathrm{BCl}_{4}^{-}$to $\mathrm{Ph}_{2} \mathrm{CH}^{+}$and $\mathrm{TolPhCH}^{+}$is not much faster than the reaction of these carbenium ions with 4 . When these experiments were performed with the weaker Lewis acid $\mathrm{ZnCl}_{2} \cdot \mathrm{OEt}_{2}$, the less stable counterion $\mathrm{ZnCl}_{3}^{-}$is produced, and $v_{-1 \mathrm{~A}}$ (or $v_{-1 \mathrm{~B}}$ ) grows relative to $v_{2 \mathrm{~A}}$ (or $v_{2 \mathrm{~B}}$ ) (Scheme 2). Consequently, case 1 becomes realized, and the $\kappa$ values derived from eq. (6) are competition constants, independent of the reactant ratio. All competition experiments have, therefore, been carried out with $\mathrm{ZnCl}_{2} \cdot \mathrm{OEt}_{2}$ as the Lewis acid.

Table 2 in the Experimental Section shows that the $\kappa$ values determined in this way are independent of the reactant ratios. Exceptions are the chloro ethers 10 and $\mathbf{1 y}$. While the $\kappa$ values determined for 10 were dependent on the reactant ratios. chloro ether $\mathbf{1 y}$ and allyltrimethylsilane (4) gave only a very low yield of $\mathbf{5 y}$ under the conditions of the competition experiments.

A poor reproducibility was also found for the relative reactivities of $\mathbf{1 g}$ and $\mathbf{l h}$. Since in this case no relationship between reactivity ratio and ratio of the reactants was observed, the averaged value given in Scheme 3 can be considered to represent the approximate reactivity of trityl chloride (1 h).
The logarithms of the competition constants give an overdetermined set of linear equations which is solved by the method of least squares to yield the $k_{\text {rel }}$ values shown in Scheme 3.

Scheme 3. Competition constants and relative reactivities of the alkyl chlorides $1 \mathrm{a}-\mathrm{x}$ towards allyltrimethylsilane (4) $\left(\mathrm{CH}_{2} \mathrm{Cl}_{2}\right.$, $\left.-70^{\circ} \mathrm{C}\right)^{[\mathrm{a}]}$

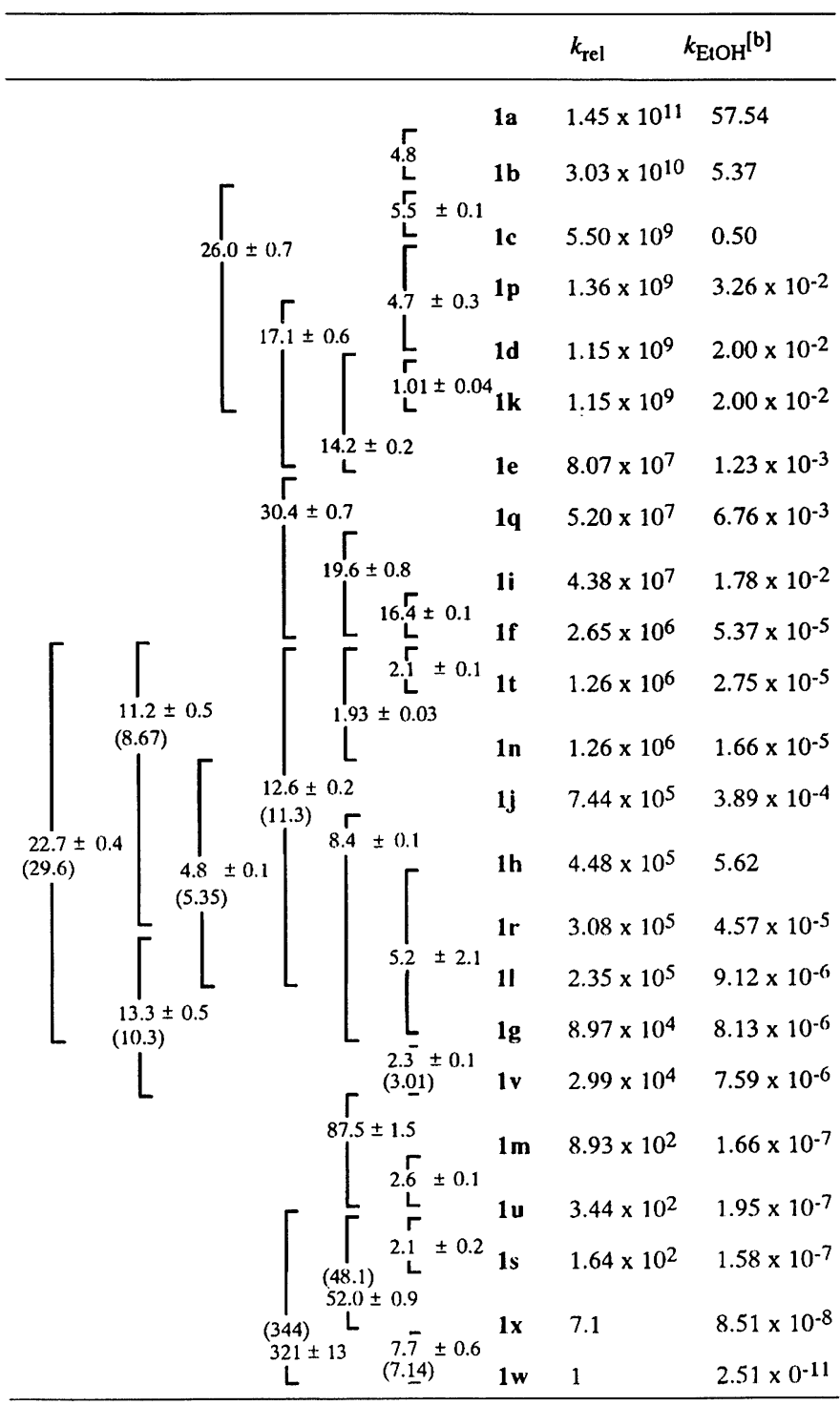

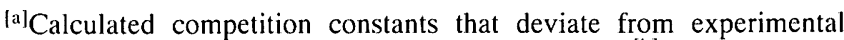
ones by more than $4 \%$ are given in parentheses. $-[b]$ Solvolysis rate constants in $100 \%$ ethanol at $25^{\circ} \mathrm{C}$. Literature data converted to these conditions according to ref. ${ }^{[19]}$. See also ref. ${ }^{[5]}$

The range of relative reactivities shown in Figure 1 covers more than eleven orders of magnitude. It is easily recognized that those precursors which form the best stabilized carbenium ions are the most reactive electrophiles in presence of catalytic amounts of $\mathrm{ZnCl}_{2} \cdot \mathrm{OEt}_{2}$.

A more detailed discussion of the relationship between structure and reactivity is superfluous since Figure 2 reveals a linear relationship between the $k_{\text {rel }}$ values determined in this work and the ethanolysis rate constants of these substrates. The same arguments, which have been used to 


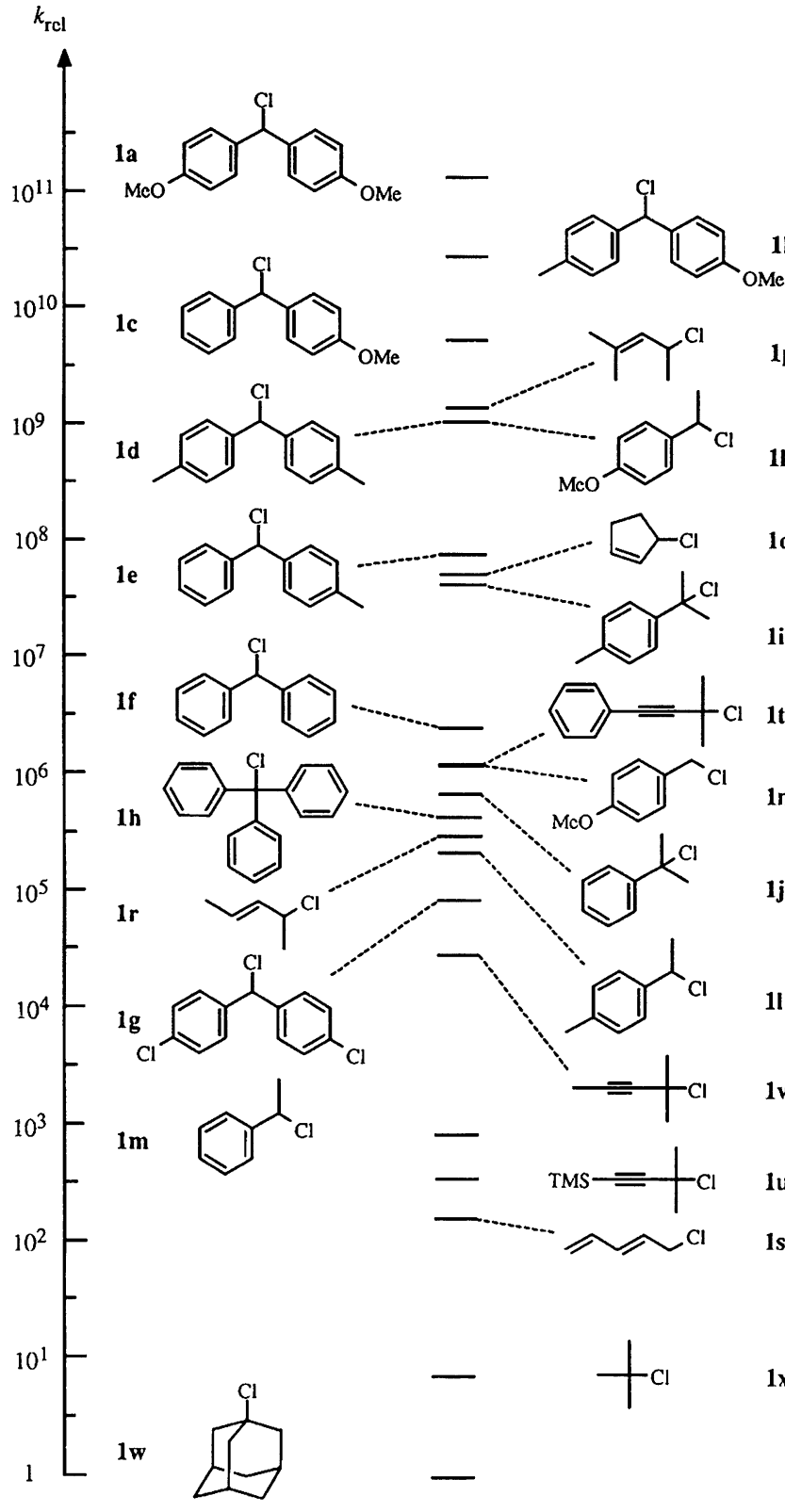

Figure 1. Relative electrophilicities of alkyl chlorides towards allyltrimethylsilane (4) (cat. $\mathrm{Zn} \mathrm{Cl}_{2}, \mathrm{CH}_{2} \mathrm{Cl}_{2},-70^{\circ} \mathrm{C}$ )

rationalize the relative $S_{N} 1$ reactivities of alkyl chlorides ${ }^{[6]}$ can, therefore, be employed to explain the reactivity order of Figure 1.

The slope of 1.036 calculated for the correlation in Figure 2 reduces to 0.7 when the different reference temperatures are taken into account (assumption: $\Delta S^{0}$ and $\Delta S^{+}$are equal for all reactions). One can conclude, therefore, that the carbenium character at the $\mathbf{1}^{+}$fragment is more developed in the ethanolysis transition states of $\mathbf{1 a}-\mathbf{y}$ than in the transition states of the Lewis acid-catalyzed reactions of $\mathbf{1}$ with 4.

Triphenylmethyl chloride (1 h) spectacularly deviates from the correlation shown in Figure 2. Its alkylating ability is approximately 100000 times smaller than expected on the basis of its $\mathrm{S}_{\mathrm{N}} 1$ reactivity. The steric strain which is built up

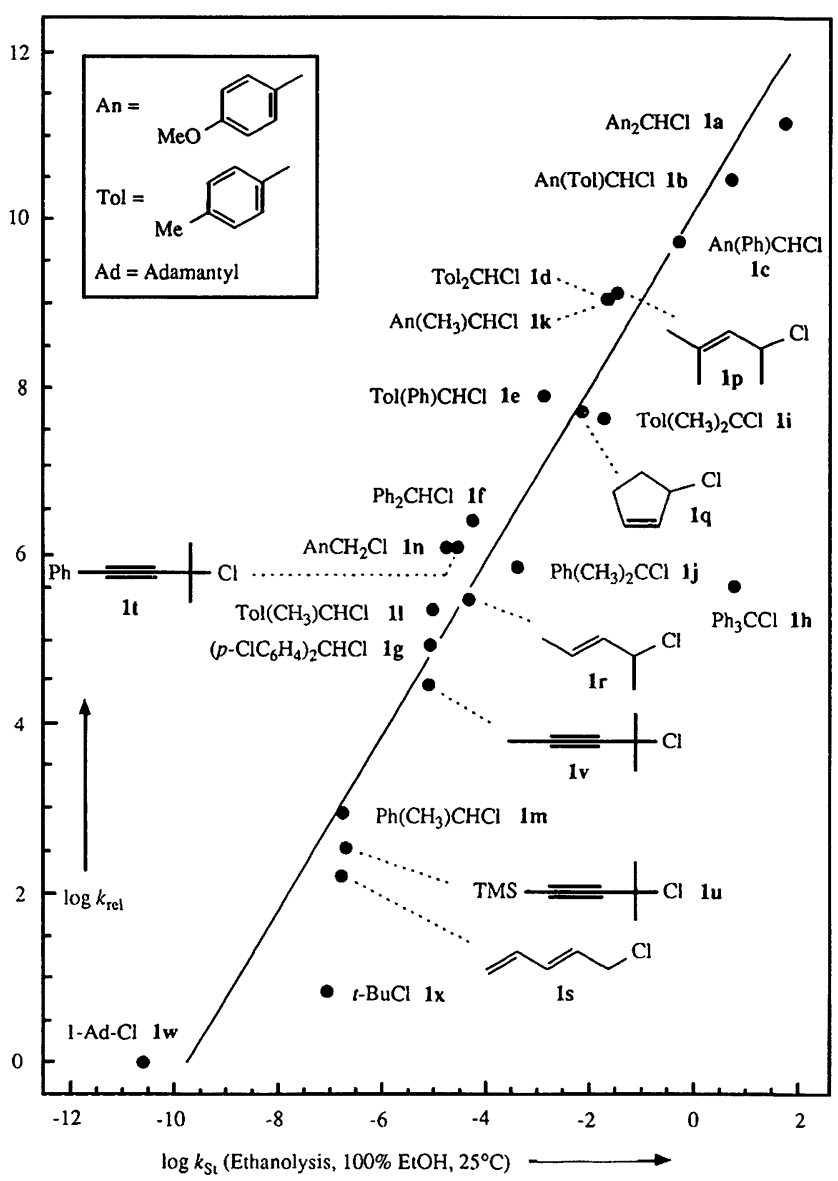

Figure 2. Correlation of the relative reactivities of alkyl chlorides $1 \mathbf{a}-\mathbf{x}$ towards allyltrimethylsilane (4) $\left(\mathrm{CH}_{2} \mathrm{Cl}_{2},-70^{\circ} \mathrm{C}\right)$ with their ethanolysis rate constants $\left(25^{\circ} \mathrm{C}\right)$. - The value for $\mathrm{Ph}_{3} \mathrm{CCl}$ has not been used for calculating the correlation equation $\log k_{\mathrm{rel}}=1.036 \log$ $k_{\mathrm{EIOH}}+10.1(r=0.971)$

during electrophilic attack of the trityl cation at $\mathbf{4}$ is obviously so great that $\mathbf{t h}$ shows an anomalously low electrophilicity. In accord with this finding, we have previously reported that the absolute rate constants for the attack of trityl cations at CC double bonds are 5000 times smaller than those of diarylcarbenium ions of the same $\mathrm{p} K_{\mathrm{R}}{ }^{+}$ value $^{[7]}$. Since other tertiary chlorides follow the same correlation as secondary and primary derivatives (Figure 2, $t \mathrm{BuCl}$ also deviates somewhat!), we have to conclude that trityl chlorides are exceptional in this respect. Steric effects are certainly not absent for the other compounds, but their magnitude appears to be small compared to the electronic effects which predominantly control the $10^{11}$ reactivity range, considered in Figure 2.

\section{Conclusion}

The formation of $1: 1$ products according to eq. (1) is possible, if the reactants $\mathbf{1}$ are more electrophilic than the products 3. Figure 2 now corroborates our earlier working hypothesis ${ }^{[2 a, 8]}$ that solvolysis rates of reactants 1 and products 3 (or suitable model compounds) can be used to predict relative electrophilicities of alkyl halides in the presence of catalytic amounts of Lewis acids. This simple relationship 
has long been masked by the fact that cationic tritylations are not easily performed, though trityl halides undergo $S_{N} 1$ reactions very rapidly. Since trityl cations are among the most intensively investigated carbenium ions, their behavior was misleading. It is now clear that trityl chlorides are abnormally poor electrophiles, and there are probably only few other types of bulky electrophiles that show similar behavior. In general, $S_{N} 1$ reactivities provide a reliable index for designing Lewis acid-catalyzed alkylations (eq. 1).

The authors gratefully acknowledge support of this work by the Deutsche Forschungsgemeinschaft and the Fonds der Chemischen Industrie.

\section{Experimental}

'H NMR: EM 390 (Varian) and XL 200 (Varian). - ${ }^{13} \mathrm{C}$ NMR: XL 200 (Varian). - MS: 70-250E (VG Instruments). - HPLC: Knauer HPLC pump 64 with Rheodyne 7125 injection valve, LDC/ Milton-Roy spectroMonitor D, and Hitachi-Merck D2000 integrator. $250 \times 4.5-\mathrm{mm}$ columns packed with Nucleosil $\mathrm{RP}_{18}, 3$ or 5 $\mu \mathrm{m}$ particles. - GC: Carlo Erba GC 6000 Vega Series 2 with $50 \mathrm{~m}$ SE-30 column.

Reactants: Commercially available allyltrimethylsilane (4) was distilled over $\mathrm{LiAlH}_{4}$ before use. Allyltripropylsilane was synthesized in analogy to a procedure described in ref. ${ }^{[4]}$ : A solution of allyl chloride $(19.1 \mathrm{ml}, 17.9 \mathrm{~g}, 0.23 \mathrm{~mol})$ in THF $(200 \mathrm{ml})$ was added dropwise $(2 \mathrm{~h})$ to a mixture of magnesium $(8.5 \mathrm{~g}, 0.35 \mathrm{~mol})$, chlorotripropylsilane $(25 \mathrm{~g}, 0.13 \mathrm{~mol})$, and THF (100 ml) kept in an ultrasound bath at $0^{\circ} \mathrm{C}$. The mixture was then stirred at $40^{\circ} \mathrm{C}$ $(2 \mathrm{~h})$ at ambient temp. $(15 \mathrm{~h})$. After addition of a saturated, solution of $\mathrm{NH}_{4} \mathrm{Cl}$ in $2 \mathrm{M}$ aqueous ammonia $(150 \mathrm{ml})$, the layers were separated, and the aqueous layer was extracted with three $50-\mathrm{ml}$ portions of ether. The combined organic layers were dried with $\mathrm{Na}_{2} \mathrm{SO}_{4}$ and distilled to give $20.8 \mathrm{~g}(81 \%)$ of allyltripropylsilane with b.p. $56-57^{\circ} \mathrm{C} / 1.7 \mathrm{mbar}$ (ref. ${ }^{[9]} 216-217^{\circ} \mathrm{C} / 748$ Torr). $-{ }^{1} \mathrm{H}$ NMR $\left(90 \mathrm{MHz}, \mathrm{CDCl}_{3}\right): \delta=0.38-0.68\left(\mathrm{~m}, 6 \mathrm{H}, \mathrm{CH}_{2} \mathrm{Si}\right), 0.95(\mathrm{t}$, $\left.J=7 \mathrm{~Hz}, 9 \mathrm{H}, \mathrm{CH}_{3}\right), 1.11-1.47\left(\mathrm{~m}, 6 \mathrm{H}, \mathrm{CH}_{2} \mathrm{CH}_{2} \mathrm{CH}_{3}\right), 1.53$ (br. $\left.\mathrm{d}, J=8 \mathrm{~Hz}, 2 \mathrm{H}, \mathrm{CH}_{2} \mathrm{CH}=\right), 4.68-5.00\left(\mathrm{~m}, 2 \mathrm{H},=\mathrm{CH}_{2}\right)$, 5.53-6.06 (m, 1 H, = $\mathrm{CH}-)$.

Alkyl chlorides 1 are either commercially available or have been obtained by treatment of the corresponding alcohols or alkenes with $\mathrm{HCl}$ (conc. aqueous or gaseous). For details see ref. ${ }^{[5]}$

General Procedure for the Reactions of $\mathbf{1} \mathbf{a}-\mathbf{y}$ with Allyltrimethylsilane (4): Compounds 1 and 4 (1.5 equivalents) were dissolved in $\mathrm{CH}_{2} \mathrm{Cl}_{2}(20 \mathrm{ml}$ per gram of 1$)$. The solutions were cooled at $-78^{\circ} \mathrm{C}$ ( $\mathrm{N}_{2}$ protection), before the catalyst $\mathrm{ZnCl}_{2} \cdot\left(\mathrm{OEt}_{2}\right)_{1.03}{ }^{[10]}(0.2$ equiv. $)$ was added. After a certain period (see Table 1), the mixture was washed with an equal volume of conc. aqueous ammonia. The phases were separated, and the organic layer was dried with $\mathrm{CaCl}_{2}$, filtered, and evaporated.

4,4-Bis(4-methoxyphenyl)-1-butene (5a): Chlorobis(4-methoxyphenyl)methane (1 a) $(2.00 \mathrm{~g}, 7.60 \mathrm{mmol})$ and $4(1.30 \mathrm{~g}, 11.4 \mathrm{mmol})$ reacted within $1 \mathrm{~h}$ to give $1.50 \mathrm{~g}(74 \%)$ of $5 \mathrm{a}$ with m.p. $38-39^{\circ} \mathrm{C}$ (from pentane) (ref. $\left.{ }^{[4]} 36.5-37.5^{\circ} \mathrm{C}\right)$. ${ }^{1} \mathrm{H}$ NMR $(90 \mathrm{MHz}$, $\mathrm{CDCl}_{3}$ ): $\delta=2.75$ (br. t, $\left.J=8 \mathrm{~Hz}, 2 \mathrm{H}, 3-\mathrm{H}\right), 3.76\left(\mathrm{~s}, 6 \mathrm{H}, \mathrm{OCH}_{3}\right.$ ), $3.92(\mathrm{t}, J=8 \mathrm{~Hz}, 1 \mathrm{H}, 4-\mathrm{H}), 4.83-5.17\left(\mathrm{~m}, 2 \mathrm{H},=\mathrm{CH}_{2}\right), 5.50-6.0$ $(\mathrm{m}, 1 \mathrm{H},=\mathrm{CH}-), 6.82,7.13\left(\mathrm{AA}^{\prime} \mathrm{BB}^{\prime}\right.$ system, $J_{\mathrm{AB}}=9 \mathrm{~Hz}, 8 \mathrm{H}$, aromatic $\mathrm{H})$.

4-(4-Methoxyphenyl)-4-(4-methylphenyl)-I-butene (5b): Chloro(4-methoxyphenyl)(4-methylphenyl)methane (1 b) $\quad(2.50 \mathrm{~g}, \quad 10.1$ $\mathrm{mmol})$ and $4(1.73 \mathrm{~g}, 15.1 \mathrm{mmol})$ reacted within $1 \mathrm{~h}$ to give $2.43 \mathrm{~g}$
(95\%) of $\mathbf{5 b}$ as a viscous oil ${ }^{[11]}$ - - ${ }^{1} \mathrm{H}$ NMR $\left(90 \mathrm{MHz}, \mathrm{CDCl}_{3}\right): \delta=$ $2.32\left(\mathrm{~s}, 3 \mathrm{H}, \mathrm{CH}_{3}\right), 2.76$ (br. $\left.\mathrm{t}, J=8 \mathrm{~Hz}, 2 \mathrm{H}, 3-\mathrm{H}\right), 3.75(\mathrm{~s}, 3 \mathrm{H}$, $\left.\mathrm{OCH}_{3}\right), 3.93(\mathrm{t}, J=8 \mathrm{~Hz}, 1 \mathrm{H}, 4-\mathrm{H}), 4.80-5.16\left(\mathrm{~m}, 2 \mathrm{H},=\mathrm{CH}_{2}\right)$, $5.46-5.97(\mathrm{~m}, 1 \mathrm{H},=\mathrm{CH}-), 6.78,7.08\left(\mathrm{AA}^{\prime} \mathrm{BB}^{\prime}\right.$-system, $J_{\mathrm{AB}}=9$ $\left.\mathrm{Hz}, 4 \mathrm{H}, \mathrm{C}_{6} \mathrm{H}_{4} \mathrm{OCH}_{3}\right), 7.05\left(\mathrm{~s}, 4 \mathrm{H}, \mathrm{C}_{6} \mathrm{H}_{4} \mathrm{CH}_{3}\right.$, superimposed by the $\mathrm{AA}^{\prime} \mathrm{BB}^{\prime}$ system).

4-(4-Methoxyphenyl)-4-phenyl-1-butene (5c): Chloro(4-methoxyphenyl)phenylmethane (1c) $(4.70 \mathrm{~g}, 20.2 \mathrm{mmol})$ and $4(3.47 \mathrm{~g}, 30.4$ mmol) reacted within $1 \mathrm{~h}$ to give $4.19 \mathrm{~g}(87 \%)$ of $\mathbf{5 b}$, colorless needles with m.p. $63.5-64^{\circ} \mathrm{C}$ (from pentane) (ref. ${ }^{[4]} 62.5-63.5^{\circ} \mathrm{C}$ ). - ' $\mathrm{H}$ NMR (90 MHz, $\mathrm{CDCl}_{3}$ ): $\delta=2.78$ (br. t, $J=8 \mathrm{~Hz}, 2 \mathrm{H}, 3-$ $\mathrm{H}), 3.76\left(\mathrm{~s}, 3 \mathrm{H}, \mathrm{OCH}_{3}\right), 3.97(\mathrm{t}, J=8 \mathrm{~Hz}, 1 \mathrm{H}, 4-\mathrm{H}), 4.83-5.17$ $\left(\mathrm{m}, 2 \mathrm{H},=\mathrm{CH}_{2}\right), 5.50-6.0(\mathrm{~m}, 1 \mathrm{H},=\mathrm{CH}-), 6.82,7.12\left(\mathrm{AA}^{\prime} \mathrm{BB}^{\prime}\right.$ system, $J_{\mathrm{AB}}=9 \mathrm{~Hz}, 4 \mathrm{H}, \mathrm{C}_{6} \mathrm{H}_{4} \mathrm{OCH}_{3}$ ), 7.26 (br. s, $5 \mathrm{H}, \mathrm{C}_{6} \mathrm{H}_{5}$, superimposed by the $\mathrm{AA}^{\prime} \mathrm{BB}^{\prime}$ system).

4,4-Bis(4-methylphenyl)-1-butene (5d) see ref. ${ }^{[12]}$ For conditions used in this work, see Table 1.

4-(4-Methylphenyl)-4-phenyl-1-butene (5e) ${ }^{[13]}$ : Chloro(4-methylphenyl)phenylmethane (1c) $(2.20 \mathrm{~g}, 10.2 \mathrm{mmol})$ and $4(1.71 \mathrm{~g}, 15.0$ mmol) reacted within $1 \mathrm{~h}$ to give $2.05 \mathrm{~g}(91 \%)$ of $5 \mathrm{e}$ with b.p. $120^{\circ} \mathrm{C}$ (bath) $/ 4 \cdot 10^{-5}$ mbar. $-{ }^{1} \mathrm{H}$ NMR $\left(90 \mathrm{MHz}, \mathrm{CDCl}_{3}\right): \delta=2.27$ (s, $3 \mathrm{H}, \mathrm{CH}_{3}$ ), 2.78 (br. t, $\left.J=8 \mathrm{~Hz}, 2 \mathrm{H}, 3-\mathrm{H}\right), 3.95$ (t, $J=8 \mathrm{~Hz}, 1 \mathrm{H}$, 4-H), 4.80-5.15 (m, 2 H, = $\left.\mathrm{CH}_{2}\right), 5.46-5.97(\mathrm{~m}, 1 \mathrm{H},=\mathrm{CH}-), 7.10$ (s, $\left.4 \mathrm{H}, \mathrm{C}_{6} \mathrm{H}_{4} \mathrm{CH}_{3}\right), 7.22\left(\mathrm{mc}, 5 \mathrm{H}, \mathrm{C}_{6} \mathrm{H}_{5}\right)$.

4,4-Diphenyl-1-butene (5f) see ref. ${ }^{[12]}$ For conditions used in this work, see Table 1.

4,4-Bis(4-chlorophenyl)-1-butene (5g) ${ }^{[13]}$ : Chlorobis(4-chlorophenyl)methane $(1 \mathrm{~g})(2.00 \mathrm{~g}, 7.40 \mathrm{mmol})$ and $4(1.27 \mathrm{~g}, 11.1 \mathrm{mmol})$ reacted within $3 \mathrm{~h}$ to give $1.84 \mathrm{~g}(90 \%)$ of $5 \mathrm{~g}$ as a viscous oil. ${ }^{1} \mathrm{H} \mathrm{NMR}\left(90 \mathrm{MHz}, \mathrm{CDCl}_{3}\right): \delta=2.73$ (br. t, $J=8 \mathrm{~Hz}, 2 \mathrm{H}, 3-\mathrm{H}$ ), $3.95(\mathrm{t}, J=8 \mathrm{~Hz}, 1 \mathrm{H}, 4-\mathrm{H}), 4.82-5.15\left(\mathrm{~m}, 2 \mathrm{H},=\mathrm{CH}_{2}\right), 5.42-5.92$ $(\mathrm{m}, 1 \mathrm{H},=\mathrm{CH}-), 6.95-7.33(\mathrm{~m}, 8 \mathrm{H}$, aromatic $\mathrm{H})$.

4,4,4-Tripheny/-1-butene $(\mathbf{5} \mathbf{h})$ see ref. $^{[7]}$ For conditions used in this work, see Table 1.

4-Methyl-4-(4-methylphenyl)-1-pentene (5i): 2-Chloro-2-(4-methylphenyl)propane (1i) $(0.84 \mathrm{~g}, 5.0 \mathrm{mmol})$ and $4(0.86 \mathrm{~g}, 7.5 \mathrm{mmol})$ were combined for $2 \mathrm{~h}$ to yield $800 \mathrm{mg}(92 \%)$ of $5 \mathbf{i}$ with b.p. $70^{\circ} \mathrm{C}$ (bath)/1 mbar. - ' $\mathrm{H} \mathrm{NMR}\left(200 \mathrm{MHz}, \mathrm{CDCl}_{3}\right): \delta=1.28(\mathrm{~s}, 6 \mathrm{H}$, $\mathrm{CH}_{3}$ ), 2.32 (s, $3 \mathrm{H}$, aryl- $\mathrm{CH}_{3}$ ), 2.35 (br. d, $J=7.2 \mathrm{~Hz}, 2 \mathrm{H}, 3-\mathrm{H}$ ), $4.89-5.03\left(\mathrm{~m}, 2 \mathrm{H},=\mathrm{CH}_{2}\right), 5.45-5.68(\mathrm{~m}, 1 \mathrm{H},=\mathrm{CH}-), 7.11,7.24$ $\left(\mathrm{AA}^{\prime} \mathrm{BB}^{\prime}\right.$ system, $J_{\mathrm{AB}}=8 \mathrm{~Hz}, 4 \mathrm{H}$, aromatic $\left.\mathrm{H}\right),-{ }^{13} \mathrm{C} \mathrm{NMR}$ $\left(\mathrm{CDCl}_{3}\right): \delta=20.85\left(\mathrm{q}, \operatorname{aryl}-\mathrm{CH}_{3}\right), 28.59\left(\mathrm{q}, \mathrm{CH}_{3}\right), 37.22(\mathrm{~s}, \mathrm{C}-4)$, 48.83 (t, C-3), 116.77 (t, C-1), 125.69 (d, C $), 128.72\left(\mathrm{~d}, \mathrm{C}_{m}\right), 134.85$ $\left(\mathrm{s}, \mathrm{C}_{p}\right), 135.65(\mathrm{~d}, \mathrm{C}-2), 147.55\left(\mathrm{~s}, \mathrm{C}_{i}\right) .-\mathrm{MS}(70 \mathrm{eV}), \mathrm{m} / \mathrm{z}(\%): 174$ (0.7) $\left[\mathrm{M}^{+}\right], 159(0.6), 133(100), 105(32), 93(10) .-\mathrm{C}_{13} \mathrm{H}_{18}$ : calcd. 174.14085; found 174.13798 (MS).

4-Methyl-4-phenyl-1-pentene $(\mathbf{5 j})^{[14]}$ : 2-Chloro-2-phenylpropane (1j) $(3.10 \mathrm{~g}, 20.0 \mathrm{mmol})$ and $4(3.42 \mathrm{~g}, 30.0 \mathrm{mmol})$ reacted for 60 h to yield $2.87 \mathrm{~g}(90 \%)$ of $5 \mathbf{j}$ with b.p. $50^{\circ} \mathrm{C}$ (bath) $/ 1.2$ mbar (ref. ${ }^{[14]}$ $\left.38-39^{\circ} \mathrm{C} / 0.7 \mathrm{mbar}\right) .{ }^{1} \mathrm{H}$ NMR $\left(200 \mathrm{MHz}, \mathrm{CDCl}_{3}\right): \delta=1.30(\mathrm{~s}$, $\left.6 \mathrm{H}, \mathrm{CH}_{3}\right), 2.36$ (br. d, $\left.J=7 \mathrm{~Hz}, 2 \mathrm{H}, 3-\mathrm{H}\right), 4.90-5.03(\mathrm{~m}, 2 \mathrm{H}$, = $\left.\mathrm{CH}_{2}\right), 5.45-5.70(\mathrm{~m}, 1 \mathrm{H},=\mathrm{CH}-), 7.12-7.42(\mathrm{~m}, 5 \mathrm{H}$, aromatic $\mathrm{H}) .-{ }^{13} \mathrm{C} \mathrm{NMR}\left(\mathrm{CDCl}_{3}\right): \delta=28.50\left(\mathrm{q}, \mathrm{CH}_{3}\right), 37.56$ (s, C-4), 48.84 (t, C-3), 116.88 (t, C-1), $125.50\left(\mathrm{~d}, \mathrm{C}_{p}\right), 125.78\left(\mathrm{~d}, \mathrm{C}_{o}\right), 128.01$ (d, $\left.\mathrm{C}_{m}\right), 135.51(\mathrm{~d}, \mathrm{C}-2), 149.15\left(\mathrm{~s}, \mathrm{C}_{i}\right) .-\mathrm{MS}(70 \mathrm{eV}), m /=(\%): 160$ $(0.5)\left[\mathrm{M}^{+}\right], 145(0.7), 119(100), 91(48), 79(8)$. (ref. $^{[14]} \mathrm{MS}: 160$ $\left.\left[\mathrm{M}^{+}\right], 145,119(100)\right)$.

4-(4-Methoxyphenyl)-1-pentene (5k): 1-Chloro-1-(4-methoxyphenyl)ethane (1k) $(0.80 \mathrm{~g}, 4.7 \mathrm{mmol})$ and $4(0.80 \mathrm{~g}, 7.0 \mathrm{mmol})$ reacted for $2 \mathrm{~h}$ to yield $710 \mathrm{mg}(86 \%)$ of $5 \mathrm{k}$ with b.p. $40-45^{\circ} \mathrm{C}$ 
(bath)/0.15 mbar. - 'H NMR (200 MHz, $\left.\mathrm{CDCl}_{3}\right): \delta=1.22$ (d, $\left.J=7 \mathrm{~Hz}, 3 \mathrm{H}, \mathrm{CH}_{3}\right), 2.16-2.45(\mathrm{~m}, 2 \mathrm{H}, 3-\mathrm{H}), 2.74$ (sext, $J=7$ $\mathrm{Hz}, 1 \mathrm{H}, 4-\mathrm{H}), 3.77\left(\mathrm{~s}, 3 \mathrm{H}, \mathrm{OCH}_{3}\right), 4.91-5.04\left(\mathrm{~m}, 2 \mathrm{H},=\mathrm{CH}_{2}\right)$, $5.60-5.83(\mathrm{~m}, 1 \mathrm{H},=\mathrm{CH}-), 6.84,7.11\left(\mathrm{AA}^{\prime} \mathrm{BB}^{\prime}\right.$ system, $J_{\mathrm{AB}}=8.8$ $\mathrm{Hz}, 4 \mathrm{H}$, aromatic $\mathrm{H}) .-{ }^{13} \mathrm{C} \mathrm{NMR}\left(\mathrm{CDCl}_{3}\right): \delta=21.71\left(\mathrm{q}, \mathrm{CH}_{3}\right)$, 38.91 (d, C-4), 42.87 (t, C-3), $55.16\left(\mathrm{q}, \mathrm{OCH}_{3}\right), 113.62\left(\mathrm{~d}, \mathrm{C}_{m}\right)$, $115.78(\mathrm{t}, \mathrm{C}-1), 127.80\left(\mathrm{~d}, \mathrm{C}_{0}\right), 137.27(\mathrm{~d}, \mathrm{C}-2), 139.13\left(\mathrm{~s}, \mathrm{C}_{i}\right), 157.22$ $\left(\mathrm{s}, \mathrm{C}_{p}\right) .-\mathrm{MS}(70 \mathrm{eV}), \mathrm{m} /=(\%): 176(5.2)\left[\mathrm{M}^{+}\right], 161(0.3), 135(100)$, 105 (11), 91 (5). - $\mathrm{C}_{12} \mathrm{H}_{16} \mathrm{O}$ : calcd. 176.12012; found 176.12152 (MS).

4-(4-Methylphenyl)-1-pentene (51): 1-Chloro-1-(4-methylphenyl)ethane $(1 \mathrm{l})(2.00 \mathrm{~g}, 13.0 \mathrm{mmol})$ and $4(2.22 \mathrm{~g}, 19.3 \mathrm{mmol})$ reacted for $24 \mathrm{~h}$ to yield $1.79 \mathrm{~g}(86 \%)$ of $5 \mathrm{I}$ with b.p. $43^{\circ} \mathrm{C}$ (bath)/1 mbar. - 'H NMR $\left(90 \mathrm{MHz}, \mathrm{CDCl}_{3}\right): \delta=1.20\left(\mathrm{~d}, J=7 \mathrm{~Hz}, 3 \mathrm{H}, \mathrm{CH}_{3}\right)$, $2.28\left(\mathrm{~s}, 3 \mathrm{H}\right.$, aryl- $\left.\mathrm{CH}_{3}\right), 2.04-2.45\left(\mathrm{~m}, 2 \mathrm{H}, \mathrm{CH}_{2}\right.$, superimposed by singlet of aryl- $\left.\mathrm{CH}_{3}\right), 2.70(\mathrm{sext}, J=7 \mathrm{~Hz}, 1 \mathrm{H}, 4-\mathrm{H}), 4.76-5.06(\mathrm{~m}$, $\left.2 \mathrm{H},=\mathrm{CH}_{2}\right), 5.40-5.9(\mathrm{~m}, 1 \mathrm{H},=\mathrm{CH}-), 6.98(\mathrm{~s}, 4 \mathrm{H}$, aromatic $\mathrm{H})$.

4-Phenyl-1-pentene $(\mathbf{5 m})$ see ref. ${ }^{[15]}$ For conditions used in this work, see Table 1.

4-(4-Methoxyphenyl)-I-butene (5n): 4-Methoxybenzyl chloride (1 n) $(1.00 \mathrm{~g}, 6.40 \mathrm{mmol})$ and $4(1.09 \mathrm{~g}, 9.53 \mathrm{mmol})$ reacted for 1.5 $\mathrm{h}$ to yield $880 \mathrm{mg}(85 \%)$ of $5 \mathrm{n}$ with b.p. $55-60^{\circ} \mathrm{C}$ (bath) $/ 0.9 \mathrm{mbar}$. - 'H NMR (200 MHz, $\left.\mathrm{CDCl}_{3}\right): \delta=2.26-2.43(\mathrm{~m}, 2 \mathrm{H}, 3-\mathrm{H})$, $2.61-2.74(\mathrm{~m}, 2 \mathrm{H}, 4-\mathrm{H}), 3.78\left(\mathrm{~s}, 3 \mathrm{H}, \mathrm{OCH}_{3}\right), 4.93-5.17(\mathrm{~m}, 2 \mathrm{H}$, = $\left.\mathrm{CH}_{2}\right), 5.75-6.00(\mathrm{~m}, 1 \mathrm{H},=\mathrm{CH}-), 6.83,7.11\left(\mathrm{AA}^{\prime} \mathrm{BB}^{\prime}\right.$ system, $J_{\mathrm{AB}}=8.8 \mathrm{~Hz}, 4 \mathrm{H}$, aromatic $\left.\mathrm{H}\right) .-{ }^{13} \mathrm{C} \mathrm{NMR}\left(\mathrm{CDCl}_{3}\right): \delta=34.44$, $35.76(2 \mathrm{t}, \mathrm{C}-3, \mathrm{C}-4), 55.21\left(\mathrm{q}, \mathrm{OCH}_{3}\right), 113.66\left(\mathrm{~d}, \mathrm{C}_{m}\right), 114.82(\mathrm{t}$, $\left.=\mathrm{CH}_{2}\right), 129.27\left(\mathrm{~d}, \mathrm{C}_{o}\right), 133.93\left(\mathrm{~s}, \mathrm{C}_{i}\right), 138.17(\mathrm{~d},=\mathrm{CH}-), 157.70$ $\left(\mathrm{s}, \mathrm{C}_{p}\right) .-\mathrm{MS}(70 \mathrm{eV}), m / z(\%): 162(10.5)\left[\mathrm{M}^{+}\right], 121(100), 91(6)$, $78(16), 77(12)$.

4-Methory-4-phenyl-1-butene (50) ${ }^{[16]}$ : $\alpha$-Methoxybenzyl chloride (10) $(2.00 \mathrm{~g}, 12.8 \mathrm{mmol})$ and $4(2.19 \mathrm{~g}, 19.2 \mathrm{mmol})$ reacted for 15 h to yield $1.91 \mathrm{~g}(92 \%)$ of 50 with b.p. $38^{\circ} \mathrm{C}$ (bath)/1 mbar (ref. ${ }^{[16]}$ $75^{\circ} \mathrm{C} / 2.5$ Torr $) .-{ }^{1} \mathrm{H}$ NMR $\left(90 \mathrm{MHz}, \mathrm{CDCl}_{3}\right): \delta=2.18-2.78(\mathrm{~m}$, $2 \mathrm{H}, 3-\mathrm{H}), 3.23\left(\mathrm{~s}, 3 \mathrm{H}, \mathrm{OCH}_{3}\right), 4.15(\mathrm{t}, J=8 \mathrm{~Hz}, 1 \mathrm{H}, 4-\mathrm{H})$, $4.86-5.17\left(\mathrm{~m}, 2 \mathrm{H},=\mathrm{CH}_{2}\right), 5.5 \mathrm{l}-6.03(\mathrm{~m}, 1 \mathrm{H},=\mathrm{CH}-), 7.31(\mathrm{~s}$, $5 \mathrm{H}$, aromatic $\mathrm{H}$ ).

4,6-Dimethyl-1,5-heptadiene (5p): 4-Chloro-2-methyl-2-pentene (1 p) $(2.00 \mathrm{~g}, 16.9 \mathrm{mmol}$, including $19 \%$ of 4-chloro-4-methyl-2-pentene) and allyltripropylsilane $(4.36 \mathrm{~g}, 22.0 \mathrm{mmol})$ reacted for $2 \mathrm{~h}$ to yield $1.21 \mathrm{~g}(58 \%)$ of $5 \mathrm{p}$ with b.p. $60^{\circ} \mathrm{C}$ (bath)/79 mbar. $-{ }^{1} \mathrm{H}$ NMR $\left(200 \mathrm{MHz}, \mathrm{CDCl}_{3}\right): \delta=0.92\left(\mathrm{~d}, J=6.8 \mathrm{~Hz}, 3 \mathrm{H}, 4-\mathrm{CH}_{3}\right), 1.61$ (d, $J=1.4 \mathrm{~Hz}, 3 \mathrm{H}$, cis- $\left.\mathrm{CH}_{3}\right), 1.68\left(\mathrm{~d}, J=1.4 \mathrm{~Hz}, 3 \mathrm{H}\right.$, trans- $\left.\mathrm{CH}_{3}\right)$, $1.96-2.04(\mathrm{~m}, 2 \mathrm{H}, 3-\mathrm{H}), 2.33-2.46(\mathrm{~m}, 1 \mathrm{H}, 4-\mathrm{H}), 4.89-5.04(\mathrm{~m}$, $\left.3 \mathrm{H},=\mathrm{CH}_{2}, 5-\mathrm{H}\right), 5.66-5.87(\mathrm{~m}, 1 \mathrm{H}, 2-\mathrm{H}) .-{ }^{13} \mathrm{C} \mathrm{NMR}\left(\mathrm{CDCl}_{3}\right)$ : $\delta=17.96\left(\mathrm{q}\right.$, cis $\left.-\mathrm{CH}_{3}\right), 20.75\left(\mathrm{q}, 4-\mathrm{CH}_{3}\right), 25.76\left(\mathrm{q}\right.$, trans $\left.-\mathrm{CH}_{3}\right)$, 32.50 (d, C-4), 42.01 (t, C-3), 115.23 (t, C-1), 130.05 (s, C-6), 130.69 (d, C-5), 137.65 (d, C-2). - GC-MS (70 eV), $m / z(\%): 124(1.3)$ $\left[\mathrm{M}^{+}\right], 109(1), 83(100), 67(10), 55(64), 41(46)$. - The product contains $5 \%$ of the isomeric 4,4-dimethyl-1,5-heptadiene, detected by the following NMR signals: 'H NMR $\left(200 \mathrm{MHz}, \mathrm{CDCl}_{3}\right): \delta=$ $0.95\left(\mathrm{~s}, \mathrm{CH}_{3}\right), 5.35-5.40(\mathrm{~m}, 5-\mathrm{H}, 6-\mathrm{H}) .-{ }^{13} \mathrm{C}-\mathrm{NMR}\left(\mathrm{CDCl}_{3}\right): \delta=$ 27.06 (q, 4- $\left.\mathrm{CH}_{3}\right)$. - GC-MS (70 eV), m/z (\%): 109 (1.4), 83 (100), 67 (9), 55 (62), 41 (38). - $\mathrm{C}_{9} \mathrm{H}_{16}$ : calcd. 124.12520; found 124.12535 (MS).

3-Ally/-1-cyclopentene (5q): 3-Chloro-1-cyclopentene (1q) (8.20 g, $80.0 \mathrm{mmol})$ and $4(9.70 \mathrm{~g}, 85.0 \mathrm{mmol})$ reacted for $1 \mathrm{~h}$ to yield 4.34 $\mathrm{g}(50 \%)$ of $5 \mathrm{q}$ with b.p. $88-89^{\circ} \mathrm{C} / 400$ mbar. $-{ }^{1} \mathrm{H}$ NMR $(200 \mathrm{MHz}$, $\left.\mathrm{CDCl}_{3}\right): \delta=1.35-1.54,1.96-2.36\left(\mathrm{~m}, 6 \mathrm{H}, 3 \mathrm{CH}_{2}\right), 2.64-2.84(\mathrm{~m}$, $1 \mathrm{H}, 3-\mathrm{H}), 4.95-5.09\left(\mathrm{~m}, 2 \mathrm{H},=\mathrm{CH}_{2}\right), 5.65-5.89(\mathrm{~m}, 3 \mathrm{H},=\mathrm{CH}-)$. $-{ }^{1.3} \mathrm{C} \mathrm{NMR}\left(\mathrm{CDCl}_{3}\right): \delta=29.18(\mathrm{t}, \mathrm{C}-4), 31.98(\mathrm{t}, \mathrm{C}-5), 40.21(\mathrm{t}$,
$\mathrm{CH}_{2}$, allyl part), 45.10 (d, C-3), $115.27\left(\mathrm{t},=\mathrm{CH}_{2}\right), 130.60$ (d, C-1), 134.62 (d, C-2), 137.55 (d, =CH - allyl part). - MS $(70 \mathrm{eV}), \mathrm{m} / \mathrm{z}$ (\%): 108 (1.6) $\left[\mathrm{M}^{+}\right], 77$ (2), 67 (100), 66 (10), 41 (15).

4-Methyl-1,5-heptadiene $(\mathbf{5 r})^{[17]}:$ (E)-4-Chloro-2-pentene (1r) $(9.00 \mathrm{~g}, 86.1 \mathrm{mmol})$ and $4(10.7 \mathrm{~g}, 93.6 \mathrm{mmol})$ reacted for $3 \mathrm{~h}$ to yield $3.49 \mathrm{~g}(37 \%)$ of $5 \mathrm{r}$ with b.p. $66-72^{\circ} \mathrm{C} / 397$ mbar. $-{ }^{\prime} \mathrm{H}$ NMR $\left(200 \mathrm{MHz}, \mathrm{CDCl}_{3}\right): \delta=0.96\left(\mathrm{~d}, J=6.4 \mathrm{~Hz}, 3 \mathrm{H}, 4-\mathrm{CH}_{3}\right), 1.65(\mathrm{~d}$, $J=4.8 \mathrm{~Hz}, 3 \mathrm{H}, 7-\mathrm{H}), 1.97-2.26(\mathrm{~m}, 3 \mathrm{H}, 3-\mathrm{H}, 4-\mathrm{H}), 4.90-5.05$ $\left(\mathrm{m}, 2 \mathrm{H},=\mathrm{CH}_{2}\right), 5.25-5.52(\mathrm{~m}, 2 \mathrm{H}, 5-\mathrm{H}, 6-\mathrm{H}), 5.65-5.90(\mathrm{~m}, 1 \mathrm{H}$, 2-H). $-{ }^{13} \mathrm{C} \mathrm{NMR}\left(\mathrm{CDCl}_{3}\right): \delta=17.94$ (q, C-7), 20.09 (q, 4- $\left.\mathrm{CH}_{3}\right)$, 36.43 (d, C-4), 41.54 (t, C-3), 115.45 (t, C-1), 123.02 (d, C-6), 136.82, 137.47 (2 d, C-2, C-5). - MS (70 eV), $\mathrm{m} / \mathrm{z}(\%): 110(1.2)$ $\left[\mathrm{M}^{+}\right], 95(5), 69(100), 53(5), 41(68)$.

1,3,7-Octatriene (5s): $2.00 \mathrm{~g}$ (19.5 mmol) of (E)-5-Chloro-1,3pentadiene (1s) and allyltripropylsilane $(5.02 \mathrm{~g}, 25.3 \mathrm{mmol})$ reacted for $67 \mathrm{~h}$ at $-40^{\circ} \mathrm{C}$ to yield $140 \mathrm{mg}(7 \%)$ of 5 s with b.p. $25^{\circ} \mathrm{C}$ (bath)/ 0.8 mbar. The product contains $10 \%$ of impurities (GC). $-{ }^{1} \mathrm{H}$ NMR $\left(200 \mathrm{MHz}, \mathrm{CDCl}_{3}\right): \delta=2.14-2.25(\mathrm{~m}, 4 \mathrm{H}, 5-\mathrm{H}, 6-\mathrm{H})$. $4.94-5.16\left(\mathrm{~m}, 4 \mathrm{H},=\mathrm{CH}_{2}\right), 5.46-6.42(\mathrm{~m}, 4 \mathrm{H},=\mathrm{CH}-),-{ }^{13} \mathrm{C}$ NMR $\left(\mathrm{CDCl}_{3}\right): \delta=31.93,33.34(2 \mathrm{t}, \mathrm{C}-5, \mathrm{C}-6), 114.84,115.00(2$ t, C-1, C-8), 131.29 (d, C-3), 134.43 (d, C-4), 137.18, 138.08 (2 d, C-2, C-7). - MS (70 eV), m/z (\%): $108(13.3)\left[\mathrm{M}^{+}\right], 93(14), 67$ (100), 41 (57).

4,4-Dimethyl-6-pheny/-1-hexen-5-yne (5t): 3-Chloro-3-methyl-1phenyl-1-butyne (1t) $(2.00 \mathrm{~g}, 11.2 \mathrm{mmol})$ and $4(1.92 \mathrm{~g}, 16.8 \mathrm{mmol})$ reacted for $2 \mathrm{~h}$ to yield $1.87 \mathrm{~g}(91 \%)$ of $5 \mathrm{t}$ with b.p. $40^{\circ} \mathrm{C}$ (bath)/ 0.1 mbar. - 'H NMR (200 MHz, $\left.\mathrm{CDCl}_{3}\right): \delta=1.27(\mathrm{~s}, 6 \mathrm{H}, 4-$ $\left.\mathrm{CH}_{3}\right), 2.25\left(\mathrm{dt}, J_{32}=7.2, J_{31}=1.2 \mathrm{~Hz}, 2 \mathrm{H}, 3-\mathrm{H}\right), 5.05-5.15(\mathrm{~m}$. $\left.2 \mathrm{H},=\mathrm{CH}_{2}\right), 5.90-6.13(\mathrm{~m}, 1 \mathrm{H},=\mathrm{CH}-), 7.23-7.38(\mathrm{~m}, 5 \mathrm{H}$, aromatic $\mathrm{H}) .-{ }^{13} \mathrm{C} \mathrm{NMR}\left(\mathrm{CDCl}_{3}\right): \delta=28.87\left(\mathrm{q}, 4-\mathrm{CH}_{3}\right), 31.45(\mathrm{~s}$, C-4), 47.7 (t, C-3), 80.63 (s, C-6), 96.87 (s, C-5), 117.37 (t, C-1), $123.95\left(\mathrm{~s}, \mathrm{C}_{i}\right), 127.45\left(\mathrm{~d}, \mathrm{C}_{p}\right), 128.11\left(\mathrm{~d}, \mathrm{C}_{m}\right), 131.56\left(\mathrm{~d}, \mathrm{C}_{t}\right), 135.29$ (d, C-2). - MS (70 eV), m/z (\%): $184(5.9)\left[\mathrm{M}^{+}\right], 169(2), 143(100)$, 128 (21), $115(6) .-\mathrm{C}_{14} \mathrm{H}_{16}$ : calcd. 184.12520; found 184.12568 (MS).

4,4-Dimethyl-6-(trimethylsilyl)-1-hexen-5-yne (5u): 3-Chloro-3methyl-1-(trimethylsilyl)-1-butyne $(1 \mathrm{u})(2.00 \mathrm{~g}, 11.4 \mathrm{mmol})$ and 4 $(1.90 \mathrm{~g}, 16.7 \mathrm{mmol})$ reacted for $20 \mathrm{~h}$ to yield $1.52 \mathrm{~g}(74 \%)$ of $5 \mathrm{u}$ with b.p. $70-80^{\circ} \mathrm{C}$ (bath) $/ 40$ mbar. $-{ }^{1} \mathrm{H}$ NMR $\left(200 \mathrm{MHz}, \mathrm{CDCl}_{3}\right): \delta=$ $0.10\left[\mathrm{~s}, 9 \mathrm{H}, \mathrm{Si}\left(\mathrm{CH}_{3}\right)_{3}\right], 1.14\left(\mathrm{~s}, 6 \mathrm{H}, 4-\mathrm{CH}_{3}\right), 2.12$ (br. d. $J=7.3 \mathrm{~Hz}$, $2 \mathrm{H}, 3-\mathrm{H}), 4.93-5.08\left(\mathrm{~m}, 2 \mathrm{H},=\mathrm{CH}_{2}\right), 5.78-6.02(\mathrm{~m}, 1 \mathrm{H}, 2-\mathrm{H})$. ${ }^{13} \mathrm{C}$ NMR $\left(\mathrm{CDCl}_{3}\right): \delta=0.32\left(\mathrm{q}, \mathrm{SiCH}_{3}\right), 28.78\left(\mathrm{q}, 4-\mathrm{CH}_{3}\right), 31.59$ (s, C-4), 47.60 (t, C-3), 83.54 (s, C-6), 114.22 (s, C-5), 117.22 (t, C1), 135.21 (d, C-2). - GC-MS (70 eV), $m / z(\%): 180(0.8)\left[\mathrm{M}^{+}\right]$, $165(2), 139(25), 123(12), 97$ (100), 73 (27). - The product contains $6 \%$ of the isomeric 6-methyl-4-(trimethylsilyl)-1,4,5-heptatriene (GC): ${ }^{1} \mathrm{H}$ NMR $\left(200 \mathrm{MHz}, \mathrm{CDCl}_{3}\right): \delta=1.62\left(\mathrm{~s}, \mathrm{CH}_{3}\right)$ terminal methyl groups. - GC-MS (70 eV), $m / z(\%): 180(6.8)\left[\mathrm{M}^{+}\right], 165$ (4), 139 (4), 123 (9), 97 (42), 73 (100). - $\mathrm{C}_{11} \mathrm{H}_{20} \mathrm{Si}$ : calcd. 180.13343; found 180.13345 (MS).

4.4-Dimethyl-1-hepten-5-yne (5v): 4-Chloro-4-methyl-2-pentyne (1v) $(2.20 \mathrm{~g}, 18.8 \mathrm{mmol})$ and allyltripropylsilane $(4.84 \mathrm{~g} .24 .3 \mathrm{mmol})$ reacted for $48 \mathrm{~h}$ to yield $1.15 \mathrm{~g}(50 \%)$ of $5 \mathrm{v}$ with b.p. $80^{\circ} \mathrm{C}$ (bath)/ 87 mbar. $-{ }^{1} \mathrm{H} \mathrm{NMR}\left(200 \mathrm{MHz}, \mathrm{CDCl}_{3}\right): \delta=1.15\left(\mathrm{~s}, 6 \mathrm{H}, 4-\mathrm{CH}_{3}\right)$, 1.79 (s, 3H, 7-H), 2.13 (br. d, $J=7.2 \mathrm{~Hz}, 2 \mathrm{H}, 3-\mathrm{H}$ ), $4.98-5.11$ $\left(\mathrm{m}, 2 \mathrm{H},=\mathrm{CH}_{2}\right), 5.83-6.07(\mathrm{~m}, 1 \mathrm{H},=\mathrm{CH}-) . \quad{ }^{13} \mathrm{C} \mathrm{NMR}$ $\left(\mathrm{CDCl}_{3}\right): \delta=3.48$ (q, C-7), 29.14 (q, 4-CH $\left.\mathrm{CH}_{3}\right), 30.80$ (s. C-4), 47.88 (t, C-3), 75.35 (s, C-6), 86.29 (s, C-5), 116.97 (t, C-1), 135.62 (d, C2). - MS $(70 \mathrm{eV}), \mathrm{m} /=(\mathrm{M} / 1): 122(1.1)\left[\mathrm{M}^{+}\right], 107(28), 81(100), 79$ (30), 53 (41), 41 (47).

1-Allyladamantane (5w): 1-Adamantyl chloride (1 w) $(2.00 \mathrm{~g}, 11.7$ $\mathrm{mmol})$ and $4(2.00 \mathrm{~g}, 17.5 \mathrm{mmol})$ reacted for $6 \mathrm{~d}$ at $-28^{\circ} \mathrm{C}$ and 48 
h at $0{ }^{\circ} \mathrm{C}$. The product contained $7 \%$ of $1 \mathrm{w}(\mathrm{GC})$ and was heated under reflux in acetone/water $(1: 1)$ for $60 \mathrm{~h}$ to hydrolyze $1 \mathrm{w}$. The resulting 1-adamantanol was removed by filtration through silica gel using pentane as the eluent. Distillation yields $700 \mathrm{mg} \mathrm{(34 \% )} \mathrm{of}$ 5 w with b.p. $50-55^{\circ} \mathrm{C}$ (bath) $/ 0.8$ mbar. - ${ }^{1} \mathrm{H}$ NMR $(200 \mathrm{MHz}$, $\left.\mathrm{CDCl}_{3}\right): \delta=1.22-2.02(\mathrm{~m}, 15 \mathrm{H}$, adamantyl-H), 1.94 (br. $\mathrm{s}, 2 \mathrm{H}$, $\mathrm{CH}_{2}$, allyl part, superimposed by adamantyl- $\left.\mathrm{H}\right), 4.85-5.05(\mathrm{~m}$, $\left.2 \mathrm{H},=\mathrm{CH}_{2}\right), 5.69-5.91(\mathrm{~m}, 1 \mathrm{H},=\mathrm{CH}-) .-{ }^{13} \mathrm{C} \mathrm{NMR}\left(\mathrm{CDCl}_{3}\right)$ : $\delta=28.75(\mathrm{~d}, \mathrm{C}-3), 32.66(\mathrm{~s}, \mathrm{C}-1), 37.14(\mathrm{t}, \mathrm{C}-4), 42.40(\mathrm{t}, \mathrm{C}-2)$, 49.06 (t, $\mathrm{CH}_{2}$, allyl part), $116.47\left(\mathrm{t},=\mathrm{CH}_{2}\right), 134.94(\mathrm{~d},=\mathrm{CH}-)$. MS $(70 \mathrm{eV}), m / z(\%): 176(0.9)\left[\mathrm{M}^{+}\right], 135(100), 107(5), 93(13)$, 79 (15), 67 (7).

4.4-Dimethyl-1-pentene $(5 \mathbf{x})$ : Unlike the other reactions, which were performed according to the general procedure, this reaction has been carried out without a solvent. tert-Butyl chloride (1x) (10.4 ml, $94.4 \mathrm{mmol})$ was dropped to a suspension of $4(10.4 \mathrm{~g}$, $91.0 \mathrm{mmol})$ and dry $\mathrm{ZnCl}_{2}(7.00 \mathrm{~g}, 51.2 \mathrm{mmol})$ at $0{ }^{\circ} \mathrm{C}$ within $3 \mathrm{~h}$. The mixture was kept at this temp. for $48 \mathrm{~h}$. After workup with 50 $\mathrm{ml} 5 \mathrm{~N} \mathrm{HCl}$, distillation yielded $3.56 \mathrm{~g}\left(40^{\circ} \%\right)$ of $5 \mathrm{x}$ with b.p. $73^{\circ} \mathrm{C}$.
- 'H NMR (90 MHz, $\left.\mathrm{CDCl}_{3}\right): \delta=0.90\left(\mathrm{~s}, 9 \mathrm{H}, \mathrm{CH}_{3}\right), 1.95$ (br. d, $J=8 \mathrm{~Hz}, 2 \mathrm{H}, 3-\mathrm{H}), 4.82-5.12\left(\mathrm{~m}, 2 \mathrm{H},=\mathrm{CH}_{2}\right), 5.58-6.10(\mathrm{~m}$, $1 \mathrm{H},=\mathrm{CH}-$ ).

4-Methoxy-]-butene $(5 y)^{[18]}$ : Unlike the other reactions, which were performed according to the general procedure, this reaction has been carried out without a solvent. Chloromethyl methyl ether (1y) $(11.0 \mathrm{ml}, 145 \mathrm{mmol})$ was dropped to a suspension of 4 (14.3 $\mathrm{g}, 125 \mathrm{mmol})$ and dry $\mathrm{ZnCl}_{2}(8.80 \mathrm{~g}, 64.3 \mathrm{mmol})$ at $-78^{\circ} \mathrm{C}$ within $2 \mathrm{~h}$. The mixture was kept at this temp. for $10 \mathrm{~h}$. After washing with $50 \mathrm{ml}$ of a half-saturated aqueous ammonium chloride solution, drying with $\mathrm{CaCl}_{2}$, and filtration, distillation yielded $2.60 \mathrm{~g}$ (24\%) of $5 y$ with b.p. $68^{\circ} \mathrm{C}$ (ref. ${ }^{[18]} 68-69^{\circ} \mathrm{C} / 760$ Torr). - ' $\mathrm{H}$ NMR $\left(90 \mathrm{MHz}, \mathrm{CDCl}_{3}\right): \delta=2.26(\mathrm{mc}, 2 \mathrm{H}, 3-\mathrm{H}), 3.26\left(\mathrm{~s}, 3 \mathrm{H}, \mathrm{OCH}_{3}\right)$, $3.35\left(\mathrm{t}, J=7 \mathrm{~Hz}, 2 \mathrm{H}, \mathrm{CH}_{2} \mathrm{O}\right.$, superimposed by singlet of $\left.\mathrm{OCH}_{3}\right)$, $4.87-5.18\left(\mathrm{~m}, 2 \mathrm{H},=\mathrm{CH}_{2}\right), 5.50-6.03(\mathrm{~m}, 1 \mathrm{H},=\mathrm{CH}-)$.

Competition Experiments: In order to determine the relative reactivity of two electrophiles, the competition constant $\kappa$, as defined by eqs. (6) and (8) is introduced into eqs. (5) and (7) to give (10)

Table 2. Determination of the competition constants in $\mathrm{CH}_{2} \mathrm{Cl}_{2}(10 \mathrm{ml})$ at $-70^{\circ} \mathrm{C}$

\begin{tabular}{|c|c|c|c|c|c|c|c|c|c|c|c|c|c|c|c|c|c|c|c|}
\hline & $\begin{array}{l}\mathrm{R}_{\mathrm{A}} \mathrm{Cl} \\
\mathrm{Im!}\end{array}$ & & $\begin{array}{l}\mathrm{R}_{\mathrm{B}} \mathrm{Cl} \\
\mathrm{Img}\end{array}$ & $\begin{array}{c}4 \\
/ \mathrm{nig}\end{array}$ & $\begin{array}{c}{\left[\mathrm{LA} / / \mathrm{R}_{\mathrm{A}} \mathrm{Cl}\right\}_{0}{ }^{\mid \mathrm{j}\}}} \\
\text { (molar ratio) } \\
\end{array}$ & $\begin{array}{c}{\left[\mathrm{P}_{\mathrm{A}}|/| \mathrm{P}_{\mathrm{B}}\right]} \\
\text { (molar ratio) }\end{array}$ & Tine & Standard $|b|$ & $\kappa_{A / B}[f]$ & & $\begin{array}{l}\mathrm{R}_{\mathrm{A}} \mathrm{Cl} \\
/ \mathrm{mg}\end{array}$ & & $\begin{array}{l}\mathrm{K}_{\mathrm{B}} \mathrm{O} \\
/ \mathrm{mg}\end{array}$ & $\begin{array}{c}4 \\
/ \mathrm{mg} \\
\end{array}$ & $\begin{array}{c}{[\mathrm{LA}] /\left[\mathrm{R}_{\mathrm{A}} \mathrm{Cl}\right]_{0}{ }^{[\mathrm{a}]}} \\
(\text { molar ratio) }\end{array}$ & $\begin{array}{c}{\left[\mathrm{P}_{\mathrm{A}} \mid /\left[\mathrm{P}_{\mathrm{B}}\right]\right.} \\
\text { (molar ratio) }\end{array}$ & Time & Standard $|\mathbf{b}|$ & $\kappa_{A B B}|f|$ \\
\hline la & $\begin{array}{l}18.9 \\
19.2 \\
18.6\end{array}$ & Ib & $\begin{array}{r}35.5 \\
72.0 \\
105.8\end{array}$ & $\begin{array}{l}574.6 \\
574.6 \\
574.6\end{array}$ & $\begin{array}{l}0.20^{\mid c]} \\
0.20^{\mid c]} \\
0.20^{|c|}\end{array}$ & $\begin{array}{l}3.46 \\
1.26 \\
0.71\end{array}$ & $\begin{array}{l}20 \mathrm{~min} \\
20 \mathrm{~min} \\
20 \mathrm{~min}\end{array}$ & $\begin{array}{l}\mathrm{PPT} \\
\mathrm{PPT} \\
\mathrm{PPT}\end{array}$ & $\begin{array}{c}(7.4) \\
(6.0) \\
4.8\end{array}$ & $1 p$ & $\begin{array}{l}23.7 \\
26.1 \\
22.5\end{array}$ & le & $\begin{array}{r}86.0 \\
171.5 \\
262.5\end{array}$ & $\begin{array}{l}11.4 \\
11.4 \\
11.4\end{array}$ & $\begin{array}{l}0.15^{[d]} \\
0.15 \text { [d] } \\
0.15 \text { (d] }\end{array}$ & $\begin{array}{l}7.05 \\
4.47 \\
2.12\end{array}$ & $\begin{array}{l}1 \mathrm{~min} \\
1 \mathrm{~min} \\
1 \mathrm{~min}\end{array}$ & $\begin{array}{l}\text { PHX } \\
\text { PHX } \\
\text { PHX }\end{array}$ & $\begin{array}{l}17.1 \\
18.2 \\
16.0\end{array}$ \\
\hline Ib & $\begin{array}{l}25.1 \\
25.2 \\
27.1\end{array}$ & Ic & $\begin{array}{r}47.3 \\
94.6 \\
182.3\end{array}$ & $\begin{array}{l}5.7 \\
5.7 \\
5.7\end{array}$ & $\begin{array}{l}0.20 \\
0.20 \\
0.20\end{array}$ & $\begin{array}{l}3.16 \\
1.30 \\
0.75\end{array}$ & $\begin{array}{l}75 \mathrm{~s} \\
75 \mathrm{~s} \\
75 \mathrm{~s}\end{array}$ & $\begin{array}{l}P D \\
P D \\
P D\end{array}$ & $\begin{array}{c}(6.6) \\
5.4 \\
5.6\end{array}$ & 14 & $\begin{array}{l}23.6 \\
21.3 \\
24.6\end{array}$ & If & $\begin{array}{r}82.8 \\
165.5 \\
272.4\end{array}$ & $\begin{array}{l}20.5 \\
19.4 \\
21.7\end{array}$ & $\begin{array}{l}0.20 \\
0.20 \\
0.20\end{array}$ & $\begin{array}{l}6.97 \\
3.86 \\
2.81\end{array}$ & $\begin{array}{l}1 \mathrm{~min} \\
1 \mathrm{~min} \\
1 \mathrm{~min}\end{array}$ & $\begin{array}{l}\text { PPT } \\
\text { PPT } \\
\text { PPT }\end{array}$ & $\begin{array}{l}18.2 \\
19.5 \\
21.1\end{array}$ \\
\hline 10 & $\begin{array}{l}23.4 \\
25.0 \\
26.4\end{array}$ & 1d & $\begin{array}{r}46.8 \\
101.3 \\
157.6\end{array}$ & $\begin{array}{l}5.7 \\
5.7 \\
5.7\end{array}$ & $\begin{array}{l}0.20 \\
0.20 \\
0.20\end{array}$ & $\begin{array}{l}2.43 \\
0.98 \\
0.76\end{array}$ & $\begin{array}{l}3 \mathrm{~min} \\
3 \mathrm{~min} \\
3 \mathrm{~min}\end{array}$ & $\begin{array}{l}\text { PHX } \\
\text { PHX } \\
\text { PHX }\end{array}$ & $\begin{array}{l}5.3 \\
4.1 \\
4.8\end{array}$ & If & $\begin{array}{r}64.3 \\
136.3 \\
192.7\end{array}$ & 11 & $\begin{array}{l}19.5 \\
20.0 \\
20.2\end{array}$ & $\begin{array}{l}5.7 \\
5.7 \\
5.7\end{array}$ & $\begin{array}{l}0.17(\mathrm{c}) \\
0.08^{(\mathrm{c})} \\
0.06^{[\mathrm{c}]}\end{array}$ & $\begin{array}{l}5.40 \\
13.2 \\
23.7\end{array}$ & $\begin{array}{l}2 \text { min } \\
2 \text { min } \\
2 \text { min }\end{array}$ & $\begin{array}{l}\text { HMB } \\
\text { HMB } \\
\text { HMB }\end{array}$ & $\begin{array}{l}1.9 \\
2.2 \\
2.3\end{array}$ \\
\hline Id & $\begin{array}{l}70.0 \\
70.5 \\
71.1\end{array}$ & le & $\begin{array}{l}293.8 \\
472.8 \\
570.0\end{array}$ & $\begin{array}{l}17.1 \\
17.1 \\
17.1\end{array}$ & $\begin{array}{l}0.30 \\
0.30 \\
0.30\end{array}$ & $\begin{array}{l}2.73 \\
1.69 \\
1.58\end{array}$ & $\begin{array}{l}5 \mathrm{~min} \\
5 \mathrm{~min} \\
5 \mathrm{~min}\end{array}$ & $\begin{array}{l}\text { PO } \\
\text { PO } \\
\text { PO }\end{array}$ & $\begin{array}{l}14.6 \\
13.8 \\
14.1\end{array}$ & If & $\begin{array}{l}26.4 \\
22.5 \\
26.1 \\
27.9\end{array}$ & Ir & $\begin{array}{l}113.2 \\
110.2 \\
168.5 \\
234.2\end{array}$ & $\begin{array}{l}5.7 \\
5.7 \\
5.7 \\
5.7\end{array}$ & $\begin{array}{l}0.50 \\
0.50 \\
0.50 \\
0.50\end{array}$ & $\begin{array}{l}1.32 \\
0.93 \\
0.81 \\
0.67\end{array}$ & $\begin{array}{l}22 \mathrm{~min} \\
22 \mathrm{~min} \\
22 \mathrm{~min} \\
22 \mathrm{~min}\end{array}$ & $\begin{array}{l}\text { PHX } \\
\text { PHX } \\
\text { PHX } \\
\text { PHX }\end{array}$ & $\begin{array}{l}12.2 \\
10.0 \\
11.0 \\
11.6\end{array}$ \\
\hline le & $\begin{array}{l}70.9 \\
70.3 \\
76.5\end{array}$ & $1 f$ & $\begin{array}{l}368.1 \\
557.7 \\
753.2\end{array}$ & $\begin{array}{l}17.1 \\
17.1 \\
17.1\end{array}$ & $\begin{array}{l}0.30 \\
0.30 \\
0.30\end{array}$ & $\begin{array}{l}4.40 \\
2.96 \\
2.53\end{array}$ & $\begin{array}{l}5 \mathrm{~min} \\
5 \mathrm{~min} \\
5 \mathrm{~min}\end{array}$ & $\begin{array}{l}\text { PHX } \\
\text { PHX } \\
\text { PHX }\end{array}$ & $\begin{array}{l}29.2 \\
30.3 \\
31.7\end{array}$ & $1 g$ & $\begin{array}{l}27.0 \\
27.6 \\
28.1\end{array}$ & Iv & $\begin{array}{r}45.8 \\
96.0 \\
147.4\end{array}$ & $\begin{array}{l}358 \\
358 \\
358\end{array}$ & $\begin{array}{l}0.30 \\
0.88 \\
0.88 \\
0.88\end{array}$ & $\begin{array}{l}0.01 \\
0.22 \\
0.15\end{array}$ & $\begin{array}{l}16 \mathrm{~min} \\
16 \mathrm{~min} \\
16 \mathrm{~min}\end{array}$ & $\begin{array}{l}\text { PHP } \\
\text { PHP } \\
\text { PHP }\end{array}$ & $\begin{array}{l}2.2 \\
2.2 \\
2.4\end{array}$ \\
\hline Ih & $\begin{array}{l}60.9 \\
62.7\end{array}$ & 1g & $\begin{array}{l}574.2 \\
822.7\end{array}$ & $\begin{array}{l}17.1 \\
17.1\end{array}$ & $\begin{array}{l}0.50 \\
0.50\end{array}$ & $\begin{array}{l}2.77 \\
2.11\end{array}$ & $\begin{array}{l}5 \mathrm{~min} \\
5 \mathrm{~min}\end{array}$ & $\begin{array}{l}\text { PHX } \\
\text { PHX }\end{array}$ & $\begin{array}{l}22.6 \\
23.5\end{array}$ & 10 & $\begin{array}{l}24.5 \\
20.6 \\
24.8\end{array}$ & lb & $\begin{array}{l}154.8 \\
224.1 \\
305.9\end{array}$ & $\begin{array}{l}5.7 \\
5.7 \\
5.7\end{array}$ & $\begin{array}{l}0.50 \\
0.50 \\
0.50\end{array}$ & $\begin{array}{l}7.40 \\
1.82 \\
0.59\end{array}$ & $\begin{array}{l}25 \mathrm{~min} \\
25 \mathrm{~min} \\
25 \mathrm{~min}\end{array}$ & $\begin{array}{l}\text { PHX } \\
\text { PHX } \\
\text { PHX }\end{array}$ & $\begin{array}{r}33.8 \\
15.4 \\
5.1\end{array}$ \\
\hline 1i & $\begin{array}{l}56.5 \\
28.5\end{array}$ & if & $\begin{array}{l}29.1 \\
29.5 \\
56.0\end{array}$ & $\begin{array}{l}716 \\
716\end{array}$ & $\begin{array}{l}0.08^{[d]} \\
0.08^{[d]}\end{array}$ & $\begin{array}{l}7.87 \\
4.73\end{array}$ & $\begin{array}{l}34 \mathrm{~d} \\
34 \mathrm{~d}\end{array}$ & $\begin{array}{l}\text { PHP } \\
\text { PHP }\end{array}$ & $\begin{array}{l}4.34 \\
9.21\end{array}$ & $1 r$ & $\begin{array}{l}94.2 \\
92.9 \\
94.3\end{array}$ & Iv & $\begin{array}{l}107.9 \\
212.0 \\
418.9\end{array}$ & $\begin{array}{l}358 \\
358 \\
358\end{array}$ & $\begin{array}{l}0.10 \\
0.10 \\
0.10\end{array}$ & $\begin{array}{c}11.6 \\
5.07 \\
2.83\end{array}$ & $\begin{array}{l}8 \mathrm{~min} \\
8 \mathrm{~min} \\
8 \mathrm{~min}\end{array}$ & $\begin{array}{l}E \\
E \\
E\end{array}$ & $\begin{array}{l}14.2 \\
13.3 \\
12.4\end{array}$ \\
\hline & $\begin{array}{l}21.5 \\
25.8\end{array}$ & & $\begin{array}{l}140 \\
207\end{array}$ & $\begin{array}{l}5.7 \\
5.7 \\
57\end{array}$ & $\begin{array}{l}0.50 \\
0.50\end{array}$ & $\begin{array}{l}2.70 \\
2.18 \\
3.00\end{array}$ & $\begin{array}{l}3 \mathrm{~min} \\
3 \mathrm{~min}\end{array}$ & $\begin{array}{l}\text { HMB } \\
\text { HMB }\end{array}$ & $\begin{array}{l}16.5 \\
16.3\end{array}$ & $1 v$ & $\begin{array}{r}10.2 \\
9.6 \\
9.7\end{array}$ & Iu & $\begin{array}{l}127.8 \\
261.9 \\
409.9\end{array}$ & $\begin{array}{l}716 \\
716 \\
716\end{array}$ & $\begin{array}{l}4.00 \\
4.00 \\
4.00\end{array}$ & $\begin{array}{l}7.35 \\
3.45 \\
2.34\end{array}$ & $\begin{array}{l}10 \mathrm{~min} \\
10 \mathrm{~min} \\
10 \mathrm{~min}\end{array}$ & $\begin{array}{l}\text { IO } \\
\text { IO } \\
\text { IO }\end{array}$ & $\begin{array}{l}89.9 \\
87.9 \\
84.7\end{array}$ \\
\hline Ij & $\begin{array}{l}24.7 \\
25.6 \\
24.5 \\
15.9\end{array}$ & $1 g$ & $\begin{array}{l}112.3 \\
170.8 \\
249.5\end{array}$ & $\begin{array}{l}5.7 \\
5.7 \\
5.7\end{array}$ & $\begin{array}{l}0.50 \\
0.50 \\
0.50\end{array}$ & $\begin{array}{l}3.00 \\
2.13 \\
1.33\end{array}$ & $\begin{array}{l}12 \mathrm{~min} \\
12 \mathrm{~min} \\
12 \mathrm{~min}\end{array}$ & $\begin{array}{l}\text { PO } \\
\text { PO } \\
\text { PO }\end{array}$ & $\begin{array}{l}8.4 \\
8.5 \\
8.2\end{array}$ & $1 \mathrm{~m}$ & $\begin{array}{r}15.5 \\
9.9 \\
14.2\end{array}$ & lu & $\begin{array}{l}19.3 \\
14.6 \\
75.1\end{array}$ & $\begin{array}{l}716 \\
716 \\
716\end{array}$ & $\begin{array}{l}7.30 \\
7.30 \\
7.30\end{array}$ & $\begin{array}{l}2.57 \\
1.20 \\
0.58\end{array}$ & $\begin{array}{l}31 \mathrm{~min} \\
31 \mathrm{~min} \\
31 \mathrm{~min}\end{array}$ & $\begin{array}{l}\text { PPT } \\
\text { PPT } \\
\text { PPT }\end{array}$ & $\begin{array}{l}2.7 \\
2.5 \\
2.6\end{array}$ \\
\hline & $\begin{array}{l}14.1 \\
12.0\end{array}$ & & $\begin{array}{l}174.8 \\
248.8\end{array}$ & $\begin{array}{l}4.6 \\
4.6\end{array}$ & $\begin{array}{l}0.50 \\
0.50\end{array}$ & $\begin{array}{l}1.24 \\
0.61\end{array}$ & $\begin{array}{l}16 \mathrm{~min} \\
16 \mathrm{~min}\end{array}$ & $\begin{array}{l}\text { PHX } \\
\text { PHX }\end{array}$ & $\begin{array}{c}26.7 \\
(20.5)\end{array}$ & Iu & $\begin{array}{l}17.9 \\
20.1\end{array}$ & 1s & $\begin{array}{r}41.7 \\
83.7\end{array}$ & $\begin{array}{l}716 \\
716\end{array}$ & $\begin{array}{l}18.0 \\
18.0 \\
180\end{array}$ & $\begin{array}{l}0.62 \\
0.30 \\
0.14\end{array}$ & $\begin{array}{l}31 \mathrm{~min} \\
31 \mathrm{~min}\end{array}$ & $\begin{array}{l}\text { PPT } \\
\text { PPT } \\
\text { PPT }\end{array}$ & $\begin{array}{l}2.5 \\
2.1 \\
1.7\end{array}$ \\
\hline Id & $\begin{array}{l}23.8 \\
23.5 \\
57.7\end{array}$ & $1 k$ & $\begin{array}{l}18.2 \\
38.9 \\
19.4\end{array}$ & $\begin{array}{l}5.7 \\
5.7 \\
5.7\end{array}$ & $\begin{array}{l}0.50 \\
0.50 \\
0.50\end{array}$ & $\begin{array}{l}0.93 \\
0.48 \\
2.17\end{array}$ & $\begin{array}{l}4 \min \\
4 \min \\
4 \min \end{array}$ & $\begin{array}{l}\text { PPT } \\
\text { PPT } \\
\text { PPT }\end{array}$ & $\begin{array}{l}0.96 \\
1.08 \\
0.99\end{array}$ & Iu & $\begin{array}{l}18.3 \\
21.1\end{array}$ & $\mid x$ & $\begin{array}{l}187.2 \\
374.4\end{array}$ & $\begin{array}{l}716 \\
716 \\
716\end{array}$ & $\begin{array}{l}18.0 \\
14.0 \\
14.0\end{array}$ & $\begin{array}{l}0.14 \\
2.42 \\
1.58\end{array}$ & $\begin{array}{l}20 \min \\
20 \min \end{array}$ & $\begin{array}{c}\text { PPT } \\
T \\
T\end{array}$ & $\begin{array}{r}1.7 \\
52.5 \\
53.3\end{array}$ \\
\hline if & $\begin{array}{l}22.2 \\
21.1 \\
22.2\end{array}$ & $\ln$ & $\begin{array}{l}15.7 \\
49.4 \\
97.4\end{array}$ & $\begin{array}{l}5.7 \\
5.7 \\
5.7\end{array}$ & $\begin{array}{l}0.50 \\
0.50 \\
0.50\end{array}$ & $\begin{array}{l}2.01 \\
0.60 \\
0.34\end{array}$ & $\begin{array}{l}21 \mathrm{~min} \\
21 \mathrm{~min} \\
21 \mathrm{~min}\end{array}$ & $\begin{array}{l}\text { PPT } \\
\text { PPT } \\
\text { PPT }\end{array}$ & $\begin{array}{l}1.98 \\
1.87 \\
1.94\end{array}$ & Iu & $\begin{array}{l}18.7 \\
17.5 \\
18.6\end{array}$ & lw & $\begin{array}{r}511.1 \\
1014.4 \\
1537.0\end{array}$ & $\begin{array}{l}716 \\
716 \\
716\end{array}$ & $\begin{array}{l}14.0 \\
27.0 \\
27.0 \\
27.0\end{array}$ & $\begin{array}{l}0.79 \\
9.40 \\
5.36 \\
2.94\end{array}$ & $\begin{array}{l}20 \mathrm{~min} \\
20 \mathrm{~min} \\
20 \mathrm{~min}\end{array}$ & $\begin{array}{c}\mathrm{T} \\
\mathrm{PPT} \\
\mathrm{PPT} \\
\mathrm{PPT}\end{array}$ & $\begin{array}{l}297 \\
341 \\
325\end{array}$ \\
\hline if & $\begin{array}{l}25.5 \\
26.1 \\
27.4\end{array}$ & 11 & $\begin{array}{r}95.3 \\
145.9 \\
2(x 0.3\end{array}$ & $\begin{array}{l}5.7 \\
5.7 \\
5.7\end{array}$ & $\begin{array}{l}0.50) \\
0.50 \\
0.50\end{array}$ & $\begin{array}{l}2.24 \\
1.61 \\
1.19\end{array}$ & $\begin{array}{l}42 \mathrm{~min} \\
42 \mathrm{~min} \\
42 \mathrm{~min}\end{array}$ & $\begin{array}{l}\mathrm{HMB} \\
\mathrm{HMB} \\
\mathrm{HMB}\end{array}$ & $\begin{array}{l}12.4 \\
12.9 \\
12.5\end{array}$ & Ix & $\begin{array}{l}28.7 \\
25.7\end{array}$ & lw & $\begin{array}{r}10.8 \\
51.8\end{array}$ & $\begin{array}{l}1432 \\
1432\end{array}$ & $\begin{array}{l}18.0^{\mid d]} \\
18.0^{(d)}\end{array}$ & $\begin{array}{l}31.8 \\
8.52\end{array}$ & $\begin{array}{l}27 \min \\
27 \min \end{array}$ & $\begin{array}{l}E \\
E\end{array}$ & $\begin{array}{l}6.5 \\
8.4\end{array}$ \\
\hline III & $\begin{array}{l}18.0 \\
16.1 \\
30.0 \\
\end{array}$ & 11 & $\begin{array}{r}22.4 \\
53.5 \\
182.1 \\
\end{array}$ & $\begin{array}{l}2 \times .5 \\
23.5 \\
2 x .5\end{array}$ & $\begin{array}{l}0.20 \\
0.20 \\
0.20\end{array}$ & $\begin{array}{l}3.70 \\
1.28 \\
0.69 \\
\end{array}$ & $\begin{array}{l}30 \mathrm{~min} \\
30 \mathrm{~min} \\
30 \mathrm{~min}\end{array}$ & $\begin{array}{l}\text { PPT } \\
\text { PPT } \\
\text { PPT }\end{array}$ & $\begin{array}{l}4.7 \\
4.7 \\
5.0 \\
\end{array}$ & & 29.7 & & 1011.9 & 1432 & $18.0^{\mid(4)}$ & 4.19 & $27 \min$ & $E$ & 8.1 \\
\hline
\end{tabular}

lil Lewis acid (LA): $\mathrm{ZnCl}_{2} \cdot\left(\mathrm{OEt}_{2}\right)_{1.03}$ - $-|\mathrm{b}| \mathrm{HPLC}$ analysis for the first three quarters of competition experiments (including 10/1b); GC analysis for the last quarter (starting with $\mathbf{1} \mathbf{r} / \mathbf{1} \mathbf{v}$ ). Standards: $\mathrm{IO}=$ isooctane, $\mathrm{T}=$ toluene, $\mathrm{E}=$ ethylbenzene, PPT $=1$-phenylpentane, PHX $=1$-phenylhexane, $\mathrm{PHP}=1$-phenylheptane, $\mathrm{PO}=1$-phenyloctane, $\mathrm{PD}=1$-phenyldecane, $\mathrm{HMB}=$ hexamethylbenzene. $-|\mathrm{cl}| 50 \mathrm{ml}^{\mathrm{m}}$ of $\mathrm{CH}_{2} \mathrm{Cl}_{2}$. - $|\mathrm{d}| 5 \mathrm{ml}$ of $\mathrm{CH}_{2} \mathrm{Cl}_{2}$ - $-[\mathrm{e}] \equiv 50 \%$ of $\mathrm{R}_{\mathrm{B}} \mathrm{Cl}$. - $|\mathrm{f}|$ Because of inaccurate integration (unsymmetrical peaks) the values in parentheses are not used for the calculation of the averaged competition constants. 


$$
\frac{d\left[P_{A}\right]}{d\left[P_{B}\right]}=\kappa \frac{\left[R_{A} C l\right]}{\left[R_{B} C l\right]}=-\frac{d\left[R_{A} C l\right]}{d\left[R_{B} C l\right]}
$$

which can be transformed and integrated to yield (11)

$$
\kappa=\frac{\ln \left[\mathrm{R}_{\mathrm{A}} \mathrm{Cl}\right]_{0}-\ln \left[\mathrm{R}_{\mathrm{A}} \mathrm{Cl}\right]_{\mathrm{e}}}{\ln \left[\mathrm{R}_{\mathrm{B}} \mathrm{Cl}\right]_{0}-\ln \left[\mathrm{R}_{\mathrm{B}} \mathrm{Cl}\right]_{\mathrm{e}}}
$$

Since $[\mathrm{RCl}]_{\mathrm{e}}=[\mathrm{RCl}]_{0}-[\mathrm{P}]$, eq. (11) can be rewritten:

$$
\kappa=\frac{\ln \left[\mathrm{R}_{\mathrm{A}} \mathrm{Cl}\right]_{0}-\ln \left(\left[\mathrm{R}_{\mathrm{A}} \mathrm{Cl}\right]_{0}-\left[\mathrm{P}_{\mathrm{A}}\right]\right)}{\ln \left[\mathrm{R}_{\mathrm{B}} \mathrm{Cl}\right]_{0}-\ln \left(\left[\mathrm{R}_{\mathrm{B}} \mathrm{Cl}\right]_{0}-\left[\mathrm{P}_{\mathrm{B}}\right]\right)}
$$

According to eq. (12), the calculation of $\kappa$ requires knowledge of the product concentrations $\left[\mathrm{P}_{\mathrm{A}}\right]$ and $\left[\mathrm{P}_{\mathrm{B}}\right]$ in addition to the initial concentration of the competing electrophiles. Their determination is described by the following:

Typical Procedure: Compounds $1 \mathrm{f}(22.5 \mathrm{mg}, 0.111 \mathrm{mmol}), \mathbf{1 q}$ (100.2 $\mathrm{mg}, 1.05 \mathrm{mmol}$ ), and 1-phenylhexane (internal standard, $21.5 \mathrm{mg}, 0.13 \mathrm{mmol}$ ) were placed into a $25-\mathrm{ml}$ round-bottom flask $\left(\mathrm{N}_{2}\right.$ atmosphere) and dissolved in $\mathrm{CH}_{2} \mathrm{Cl}_{2}(10 \mathrm{ml}$, freshly distilled from $\mathrm{P}_{2} \mathrm{O}_{5}$ ). The flask was sealed with a septum and cooled at $-70^{\circ} \mathrm{C}$. After $10 \mathrm{~min}, 16 \mu \mathrm{l}$ of a $3.52 \mathrm{M}$ solution of $\mathrm{ZnCl}_{2}$. $\left(\mathrm{OEt}_{2}\right)_{1.03}$ in $\mathrm{CH}_{2} \mathrm{Cl}_{2}$ was injected and $1 \mathrm{ml}$ of a $0.05 \mathrm{M}$ solution of 4 in $\mathrm{CH}_{2} \mathrm{Cl}_{2}$ was added within $2 \mathrm{~min}$. After $20 \mathrm{~min}$, methanol (5 $\mathrm{ml}$ ) and $\mathrm{K}_{2} \mathrm{CO}_{3}$ (ca. $0.1 \mathrm{~g}$ ) was added, the solid was separated by centrifugation, and the solution was analyzed by HPLC. In cases, where the product analysis was performed by GC, the Lewis acid was removed from the reaction mixture by washing with an equal volume of half-concentrated aqueous $\mathrm{NH}_{3}$. The organic solution was then dried with $\mathrm{K}_{2} \mathrm{CO}_{3}$, filtered and directly injected for $\mathrm{GC}$ analysis.

The chromatographic analysis was based on the relative peak areas of products $\left(\mathrm{P}_{\mathrm{A}}, \mathrm{P}_{\mathrm{B}}\right)$ and internal standard (1-phenylpropane, -pentane, -hexane, -heptane, -octane, -decane, or hexamethylbenzene), which were determined by HPLC (detection of the absorbance at $254 \mathrm{~nm}$ or refractive index) or GC (FID). Calibration curves based on three of four artificial mixtures of $\mathbf{5} \equiv \mathrm{P}_{A}, \mathrm{P}_{B}$ and internal standard allowed the calculation of $\left[\mathrm{P}_{\mathrm{A}}\right]$ and $\left[\mathrm{P}_{\mathrm{B}}\right]$.

Each competition experiment has been performed at least three times with variable ratios $\left[\mathrm{R}_{A} \mathrm{Cl}\right]_{0} /\left[\mathrm{R}_{\mathrm{B}} \mathrm{Cl}\right]_{0}$. Usually, the quantity of
4 was less than half of the quantity of each of the competitors in order to avoid almost complete consumption of the more reactive electrophile. In cases of very slow reactions, however, the nucleophile 4 and the Lewis acid have been used in excess to speed up the reaction, and the mixtures have been worked up prior to completion of the reactions.

[1] H. Mayr, C. Schade, M. Rubow, R. Schneider, Angew: Chem. 1987, 99, 1059-1060; Angew. Chem. Int. Ed. Engl. 1987, 26, $1029-1030$.

${ }_{\text {[2] [2a] }}$ H. Mayr, B. Seitz, I. K. Halberstadt-Kausch, J. Org. Chem. 1981, 46, 1041-1043. - [2b] H. Mayr, W. Striepe, J. Org. Chem. 1983, 48, 1159-1165.

[3] T. Sasaki, A. Usuki, M. Ohno, J. Org. Chem. 1980, 45, 3559-3564.

[4] G. Hagen, H. Mayr, J. Am. Chem. Soc. 1991, 113, 4954-4961.

[5] J.-P. Dau-Schmidt, Ph. D. Thesis, Medizinische Universität zu Lübeck, 1992.

[6] P. Vogel, Carbocation Chemistry, Elsevier, Amsterdam, 1985, chapter 7.

[7] C. Schade, H. Mayr, Makromol. Chem., Rapid Commun. 1988, 9, 477-482

[8] [8a] H. Mayr, Angew: Chem. 1981, 93, 202-204; Angew: Chem. Int. Ed. Engl. 1981, 20, 184-186. - ${ }^{[8 b]}$ H. Mayr, H. Klein, Chem. Ber: 1982, 115, 3528-3546. - ${ }^{[8 c]}$ H. Mayr, H. Klein, G. Kolberg, Chem. Ber. 1984, 117, 2555-2579.

[9] A. V. Topchiev, N. S. Nametkin, S. G. Durgar'yan, Issled. v Obl. Kremniiorgan, Soedin., Sintez i Fiz-Khim. Svoistva, Akad. Nank SSSR. Inst. Neftekhim Sinteza, Sb Statei 1962, 28-55; Chem. Abstr: 1963, 59, 1670g

${ }^{[10]}$ H. Mayr, W. Striepe, J. Org. Chem. 1985, 50, 2995-2998

[11] R. Schneider, Ph. D. Thesis, Universität Erlangen-Nürnberg, 1987.

[12] H. Mayr, R. Pock, Tetrahedron 1986, 42, 4211-4214.

[13] C. Schade, Ph. D. Thesis, Medizinische Universität zu Lübeck, 1988

${ }^{[14]}$ B. Åkermark, A. Ljungqvist, J. Organomet. Chem. 1978, 149. $97-112$.

[15] H. Lehmkuhl, W. Bergstein, D. Henneberg, E. Janssen, O. Olbrysch, D. Reinehr, G. Schomburg, Liebigs Ann. Chem. 1975, $1176-1192$.

${ }^{[16]}$ S. Torii, T. Inokuchi, S. Takagishi, H. Horike, H. Kuroda, K. Uneyama, Bull. Chem. Soc. Jpn. 1987, 60, 2173-2188.

[17] A. Hosomi, T. Imai, M. Endo, H. Sakurai, J. Organomet. Chem. $1985,285,95-107$.

[18] P. E. Peterson, B. R. Bonazza, J. Am. Chem. Soc: 1972, 94. $5017-5023$.

${ }^{[19]}$ T. W. Bentley, J.-P. Dau-Schmidt, G. Llewellyn, H. Mayr, J. Org. Chem. 1992, 57, 2387-2392.

[254/93] 